\title{
DISLOCACIONES, HEGEMONIZACIÓN DISCURSIVA E IDENTIDAD. UNA LECTURA DE MEMORIA VISUAL DE UNA NACIÓN DESDE EL POST- MARXISMO DE LACLAU Y MOUFFE
}

\author{
Hernán Cuevas Valenzuela ${ }^{1}$
}

\section{Resumen / Abstract}

Este artículo presenta un análisis del mural titulado Memoria Visual de una Nación (MVN), y en particular de su panel Los Conflictos, del reconocido artista chileno Mario Toral. Este análisis aplica algunos de los conceptos claves de la teoría del discurso post-fundacional y post-marxista (TDPP) de Ernesto Laclau e intenta probar su utilidad para el análisis cultural. La representación de acontecimientos divisivos en MVN plantea las siguientes preguntas: ¿por qué Toral incluye temas conflictivos en un mural que representa la identidad nacional y memoria? Y, ¿cómo enfrentó Toral el problema de representar la identidad nacional ante una historia traumática? El artículo primero se ocupa de la interconexión entre la producción de significado y el contexto político y social, y aborda luego la tensión entre la producción cultural y política hegemónica.

Palabras clave: cultural studies, teoría del discurso, identidad, sociedad dividida /trauma, politica chilena, Ernesto Laclau, Mario Toral.

\section{DISLOCATIONS, DISCURSIVE HEGEMONIZATION AND IDENTITY. AREADING OF MEMORIA VISUAL DE UNA NACIÓN FROM THE VIEWPOINT OFPOSTMARXISM OF LACLAU AND MOUFFE}

This article presents an analysis of the mural entitled Memoria Visual de una Nación (Visual Memory of a Nation) with a focus on its panel Los Conflictos (The Conflicts), by the renowned Chilean artist Mario Toral. This analysis applies some of the key concepts of Ernesto Laclau's post-fundaitional and post-marxist discourse theory to a Cultural Studies problematic. The representation of divisive events in MVN raises the following questions: Why did Toral include conflictive issues in a mural representing national identity and memory? And, how did Toral deal with national identity and its demand for unity when faced with a divisive and traumatic history? The article deals first with the interconnectedness of meaning-making, social, and political context and then addresses the tension between the realm of cultural production and hegemonic politics.

Keywords: cultural studies, discourse theory, identity, divided society/trauma, politics, Ernesto Laclau, Mario Toral.

\footnotetext{
${ }^{1}$ Chileno. Investigador INAP, Universidad de Chile. Investigador Responsable Fondecyt 1150788.
} 


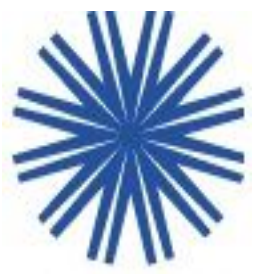

\section{Introducción}

Este artículo tiene 3 objetivos. Primero, demostrar la utilidad de la Teoría del Discurso Postfundacional y Postmarxista (en adelante TDPP) de Ernesto Laclau y Chantal Mouffe para el análisis cultural. El segundo objetivo es mostrar que la TDPP nos ayuda a visibilizar la dimensión política de toda producción cultural (y simbólica) y, por extensión, de la producción de la realidad social en general. En tercer lugar, el artículo persigue demostrar que los objetos del análisis cultural (y político) permanecen abiertos, disponibles para ser rearticulados y reinterpretados.

Como atestiguan numerosos estudios sobre el populismo, movimientos sociales, identidades sociopolíticas e ideologías políticas, las categorías clave de la TDPP son útiles para llevar a cabo análisis sociopolíticos, (Laclau 1986, 2005, Laclau (ed.) 1994, Howarth et al. (eds.) 2000, Howarth y Griggs 2011, Howarth y Torfing (eds.) 2005, Panizza (ed.) 2009, Vezovnik 2012). ¿Pero pueden esas categorías aplicarse a otros ámbitos? Hay buenas razones para pensar que TDPP también puede ser utilizada con buenos resultados en el análisis cultural, como ya lo sugieren algunos trabajos (Carpentier y De Cleen 2007, Carpentier y Spinoy (eds.) 2008, Cuevas 2008, 2015a, Mouffe 2013). Acá afirmaré que una clave para comprender este potencial desarrollo y expansión de la aplicabilidad de la TDPP a diferentes ámbitos de investigación cultural está en su concepción de las prácticas sociales como prácticas discursivas o, mejor, como discursos, que siempre combinan las dimensiones semiótica y política.

En lo que respecta al segundo objetivo, relativo a la dimensión política de toda producción cultural (simbólica), optamos por estudiar el mural Memoria Visual de una Nación (en adelante MVN) del artista plástico Mario Toral. ${ }^{2}$ Debido a que MVN trata

\footnotetext{
${ }^{2}$ El artista chileno Mario Toral (1934) estudió en Santiago (Chile), Montevideo (Uruguay) y París (Francia). Desde sus primeros años viajó a través de América Latina, Europa y los Estados Unidos. Ha participado con éxito en numerosas Bienales de arte y ha recibido varios premios internacionales. Sus obras han sido exhibidas alrededor del mundo y han sido adquiridas por algunos de los museos y coleccionistas más importantes. Durante los años del gobierno de Pinochet, vivió en Nueva York y España, regresando a Chile
} 
con cuestiones de identidad y narrativas históricas, además de la inherente arista política de todo objeto cultural, como se verá MVN revela la dimensión traumática y de antagonismo que es consustancial a lo social; esta es una dislocación que la política consensual que la élite chilena ha intentado negar o reprimir en su afán de producir gobernabilidad política, orden y cohesión social.

En lo referido al tercer objetivo, el artículo demuestra que MVN es una obra abierta, que el discurso de Toral no logra imponer una interpretación o suturar el campo de la discursividad. En este sentido, la relación significativa fundamental en el análisis cultural entre texto ( $u$ objeto) y contexto nunca finaliza del todo, pues cambios de contexto pueden bien producir cambios en el proceso de significación (Turner 2003). En el caso concreto de nuestro análisis, la contingencia del proceso de significación y la historicidad de los significados se encargan de mantener a MVN como una "obra abierta" (Eco 1992). Ahora bien, la resignificación producto del cambio de circunstancias históricas ocurre de manera singular en una expresión a la vez pública y política, como es el muralismo, cuyos símbolos e imaginario son colectivos -y no puramente idiosincráticos- y pueden siempre ser reinterpretados por nuevos espectadores. Como veremos, las redescripciones y resignificaciones pueden adquirir la capacidad de interpelar a individuos, grupos y la sociedad en general.

En este artículo asumo que la reflexividad es una dimensión importante de toda investigación social (Bourdieu y Wacquant 1992). Por ello, quisiera partir por mostrar mi experiencia como investigador, cómo ésta se entrelaza con los objetivos de investigación, y que éstos factores intervienen en la propia definición del objeto de estudio.

Es común creer que la trayectoria intelectual y laboral de un académico se haya determinada por su agenda de investigación. Esto es, como si estuviera determinada por

en 1992. Desde entonces, ha estado involucrado en la formación de nuevas generaciones de artistas en la Pontificia Universidad Católica de Chile y en la Universidad Finnis Terrae (Chile). 
una serie decisiones soberanas sobre temas de interés en torno de los que giran sus proyectos de investigación, publicaciones y, con algo de suerte, también su docencia. Pero esta es una imagen ciertamente ilusoria, pues como ocurre con toda trayectoria de laboral, el trabajo de un académico también se haya constreñido por las condiciones contextuales que lo afectan Como muchos investigadores chilenos de mi generación (1969), mis investigaciones han estado marcadas por el ciclo político de politización (1960s y 1970s), quiebre de la democracia e instauración autoritaria (1973-1988/1990) y redemocratización (1988/1990 a la actualidad). Este ciclo político ha impuesto sobre muchos de mi generación una estructura de preferencias y unas afinidades electivas que nos llevaron a problematizar los más variados temas con este dramático telón de fondo. Los estudios sobre estética y producción cultural no han sido la excepción, y ciertamente no lo ha sido en mi propia experiencia (Ariztía (ed.), 2012; Brunner, 1988; Ivelic, y Galaz, 1988; Lillo, 2009). Pero la estructuración histórica de las temáticas de investigación no se opone a la influencia de hechos imprevistos y aparentemente casuales.

Tal es el caso de la fortuita relación que se ha ido estableciendo a lo largo de mis propios estudios entre mi interpretación del mural MVN del artista Mario Toral (Santiago, 1934), con la TDPP de los teóricos políticos Ernesto Laclau (1935, Buenos Aires-2014, Sevilla) y Chantal Mouffe (Charleroi, 1943). Mi primer encuentro como investigador con MVN data de 2003-4, cuando escribía mi tesis de MPhil en Estudios Culturales en Birmingham acerca de la producción cultural en el contexto de la transición negociada y la democracia post-transicional en Chile. El foco de ese estudio fue analizar la dimensión política del mural MVN, la obra más grande de su tipo en Latino América (más de 1.200 metros cuadrados). Este monumental mural está ubicado en la estación de metro Universidad de Chile, una de las más importantes y concurridas de Santiago de Chile, y cubre sus principales muros. ${ }^{3}$ La corporación público-privada MetroArte hizo posible su

\footnotetext{
${ }^{3}$ El muralismo es un estilo artístico y una práctica visual con reglas, códigos, historia y tradiciones propias. Incluye formas de alta cultura y expresiones populares. Cualquiera sea el nivel en el que nos fijemos Bellas Artes o la cultura popular común — el muralismo se define como arte público (i.e., arte sobre asuntos públicos que se encuentra frecuentemente en lugares públicos). En América Latina, tuvo un impulso ideológico, por cierto, muy evidente en el influjo del marxismo y el nacionalismo en los grandes maestros mexicanos Rivera, Orozco y Siqueiros. También hay una historia del muralismo en Chile. Siqueiros estuvo exiliado en Chile entre 1941 y 1942. En este período realizó el maravilloso Mural de la Escuela México en la ciudad de Chillán. Este es un ejemplo de una influencia temprana del muralismo en generaciones de artistas chilenos como Gregorio de la Fuente. Una segunda corriente de la pintura mural que ha influenciado a Toral es el muralismo político y popular de colectivos como el comunista Brigada Ramona Parra (BRP).
} 
producción, la que fue muy significativamente financiada por una entidad de la banca chilena gracias a una ley de donaciones culturales.

MVN es no sólo importante como obra mural, para mí era especialmente interesante debido a que expresaba las tensiones entre conflicto sociopolítico y reconciliación nacional como pocas veces lo había visto. En ese entonces me pareció un caso ejemplar de producción cultural en un contexto post-dictatorial de una transición negociada hacia la democracia. Hoy, luego del "relanzamiento" y finalización de MVN en Diciembre de 2015, 17 años después de su inauguración en 1999 y 25 años después de la instauración de la nueva democracia, ese carácter de ejemplaridad se ve reafirmado. Como espero quedará demostrado en este artículo, la historia de MVN refleja en su "larga" producción y recepción el carácter negociado de la transición chilena y la pervivencia de legados autoritarios en la democracia post-dictatorial no sólo en el ámbito de las instituciones políticas -aspecto muy estudiado por autores como Garretón (2008) o Huneeus (2013)- sino también en la esfera cultural.

La obra de Laclau y Mouffe me ofrecía un marco teórico adecuado para la interpretación de MVN debido a su énfasis en la dimensión discursiva de la lucha por la hegemonía. La TDPP me permitía establecer como punto de partida de mis análisis culturales la imbricación entre a) la dimensión discursiva de la realidad y los procesos de significación (o semiosis) y b) la lucha por la hegemonía y el proceso político. Pero ¿Qué legitimidad podría tener esta operación teórica en el campo del análisis cultural?

El uso de la TDPP no es completamente extraño en los estudios culturales. En efecto, Hegemonía y Estrategia Socialista (original en inglés de 1985) tuvo influencia en el desarrollo de los Estudios Culturales Británicos; y en especial sobre su máximo exponente, Stuart Hall (Kingston, 1932 - Londres, 2014) (Slack 1996). Además, tanto la TDPP como los Estudios Culturales británicos presentan un origen común: el encuentro entre la radicalización de la lingüística estructural y la semiótica con el marxismo, especialmente en su versión más culturalista influenciada por Gramsci (Hall 1980, Hall 
et al. 1982, Laclau y Mouffe 2010). Esta afinidad entre la TDPP de Laclau (y Mouffe) y los Estudios Culturales de Hall ciertamente que facilitaba este préstamo de los conceptos de la TDPP al análisis cultural. En particular, los conceptos de discurso, antagonismo/dislocación y hegemonía (Laclau 1990, Laclau y Mouffe 2010) complementan muy bien los enfoques característicos de los Estudios Culturales británicos centrados en la articulación de los procesos de producción, circulación y recepción (consumo) de los objetos culturales y la significación (du Gay et al. 2013, Hall et al. 1982, Hall 1980, 1997).

A pesar de dichas afinidades, a mediados de la década 2000 el trabajo de Laclau (y Mouffe), aunque altamente influyente en las ciencias sociales posestructuralistas, no era usado para producir estudios sistemáticos de las artes y la cultura (popular). ${ }^{4}$ Poner al día a los estudios culturales en este aspecto era una tarea muy ambiciosa que no podía realizarse por un solo investigador, y menos en un solo capítulo o artículo. Mi contribución de entonces tuvo un propósito más realista y acotado, aunque no por ello fácil de abordar, pues obedecía a un doble objetivo: primero, mostrar que algunas de las principales categorías de la TDPP de Laclau (y Mouffe) pueden ser provechosamente aplicadas para entender la producción de objetos culturales en su contexto social y político; y, segundo, demostrar que los Estudios Culturales británicos, con su énfasis en la producción y circulación de los significados y en los procesos contingentes de codificación y decodificación, ofrecen un modelo complementario para explicarnos la recepción de las interpelaciones discursivas por parte de los sujetos activos. Esta última perspectiva agrega elementos interesantes a las teorías de raíz lacaniana acerca de la identificación del sujeto que son favorecidas por la TDPP. En conjunto, estos enfoques me permitían comprender el "texto" visual de Toral en dos clases de contexto: 1) de luchas sociopolíticas y 2) de procesos concretos de apreciación estética (Cuevas 2008). ${ }^{5}$

\footnotetext{
${ }^{4}$ Hay algunas interesantes discusiones al respecto, que se centran especialmente en la categoría de articulación (Slack, 1996; también véase Stuart Hall, 1997). Esto se suma principalmente al crédito de Stuart Hall.

${ }^{5}$ Esta investigación fue realizada entre 2003 y 2004 en el marco de una tesis de postgrado. Si bien la publicación referida presenta una parte significativa de la misma, por razones de espacio no aborda el contexto sociopolítico de MVN.
} 
Lo que resta de este artículo se estructura de la siguiente manera. Luego de esta ntroducción, en la sección 2 presento algunos de los conceptos fundamentales de la TDPP. Su exposición será útil para comprender en subsecuentes secciones los análisis del mural MVN. La tercera sección, la más larga del artículo, aborda el análisis sustantivo del mural de MVN. El artículo presenta en su última sección tres conclusiones principales. Primero, que MVN es una obra compleja, cuya historia demuestra que como todo objeto cultural, permanece abierto a la interpretación. Segundo, que su significación es política y refleja antagonismos y dislocaciones no resueltas. Tercero, que los conceptos de discurso, articulación, hegemonía y antagonismo elaborados por Ernesto Laclau y Chantal Mouffe son de gran utilidad para este tipo de análisis cultural.

\section{El cuadrilátero fundamental de la TDPP: Discurso, Articulación, Hegemonía y Antagonismo}

En recuentos recientes acerca de la historia y desarrollo de la TDPP, Laclau (2014) y Mouffe (2013) han señalado la centralidad de los conceptos de antagonismo y hegemonía en su enfoque. A ellos, cabría agregar los de discurso y articulación. En conjunto, estos constituyen lo que he llamado el cuadrilátero fundamental de la TDPP, pues constituyen los pilares de su ontología social.

\section{Discurso}

Para explicar el concepto de discurso de la TDPP es útil partir señalando que este cuerpo teórico se funda en una ontología social que rechaza la ilusión de la inmediatez; esto es, sostiene que no es posible tener acceso a la realidad de manera directa, nomediada. Contrario al sentido común, la TDPP sostiene que sólo se puede acceder a la realidad por medio de la mediación de categorías discursivas, sistemas de significados o sistemas de representaciones. En el vocabulario propio de la TDPP, esta función de mediación la cumplen los discursos. El antecedente inmediato de esta concepción de la TDPP es el concepto de sobredeterminación y la teoría de la ideología de Louis Althusser (Althusser 1969: 87 ff., 1971: 127-186, 1990: 1-42). Althusser utiliza el concepto de sobredeterminación para explicar el carácter complejo de la realidad, en cuya producción intervienen múltiples niveles y causalidades (Althusser 1969). Sin embargo, el admite que el concepto de sobredeterminación tiene su origen y uso preciso en el psicoanálisis. Freud lo utiliza para dar cuenta del trabajo del sueño y los procesos de condensación y desplazamiento que, como señalan Laclau y Mouffe, son procesos que por supuesto 
tienen lugar en un nivel simbólico. Laclau y Mouffe (2010) radicalizan esta interpretación de la sobredeterminación, la que estaba incompleta en Althusser (Cuevas 2015c). Vale la pena citar in extenso esta sección fundamental en la que Laclau y Mouffe justifican su interpretación teórica y su decisión, la que tendrá profundas consecuencias en su teorización de los conceptos de discurso y articulación:

El concepto de sobredeterminación se constituye en el campo de lo simbólico, y carece de toda significación al margen del mismo. Por consiguiente, el sentido potencial más profundo que tiene la afirmación althusseriana de que no hay nada en lo social que no esté sobredeterminado, es la aserción de que lo social se constituye como orden simbólico. El carácter simbólico —es decir, sobredeterminado—de las relaciones sociales implica, por tanto, que éstas carecen de una literalidad última que las reduciría a momentos necesarios de una ley inmanente. No habría, pues, dos planos, uno de las esencias y otro de las apariencias, dado que no habría la posibilidad de fijar un sentido literal último, frente al cual lo simbólico se constituiría como plano de significación segunda y derivada. La sociedad y los agentes sociales carecerían de esencia, y sus regularidades consistirían tan sólo en las formas relativas y precarias de fijación que han acompañado a la instauración de un cierto orden. (Laclau y Mouffe, 2010: 134)

De lo anterior se deriva que para la TDPP las identidades, entidades externas o eventos, nunca se nos ofrecen como esencias independientes con significados que les son inherentes. El significado de todo evento, objeto o identidad sólo se nos puede dar como el resultado de una mediación simbólica e imaginaria; es decir, como parte de una secuencia significativa o discurso (Laclau y Mouffe, 2010: 134-135).

¿Pero cómo definir más precisamente qué es un discurso? Para Laclau y Mouffe (2010: 142-143) un discurso es una "totalidad estructurada" producida por "prácticas 
articulatorias". ${ }^{6}$ En su sentido más general, este concepto de discurso se refiere a que todo sujeto, objeto o acción concretos, obtiene su sentido o significado de un sistema de diferencias significantes del que participa (Howarth, 2000: 101). O, dicho de otro modo, el significado de todo objeto, identidad o evento es conferido por un sistema de distinciones o discurso. Es común encontrarse con el malentendido de que La TDPP no cuestiona la existencia de toda realidad externa al pensamiento. ${ }^{7}$ Lo que sí cuestiona es la afirmación de que los objetos de la realidad "puedan constituirse como objetos al margen de toda condición discursiva de emergencia.” (Laclau y Mouffe 2010: 66) Afirmar que un objeto se constituye "como objeto de discurso" es afirmar que éste adquiere significado sólo en tanto participa de un discurso. Permítaseme insistir: esto no niega que exista un mundo de objetos exterior al pensamiento; sólo afirma que la especificidad significativa de los objetos "depende de la estructuración de un campo discursivo." (Ibíd: 146).

En este nivel de abstracción, la categoría de discurso se refiere a la ontología social. Por el bien del análisis empírico, varios comentaristas han suscrito la necesidad de producir un concepto operativo de discurso. En esta línea, David Howarth y Yannis Stavrakakis, proponen una definición menos abstracta: "el discurso o los discursos se refieren a sistemas de prácticas significativas que forman identidades de sujetos y objetos" (2000: 3-4). De este modo, un discurso empírico puede ser comprendido como una "organización de significado relativamente unificada y coherente", que es "históricamente construido" en procesos políticos conflictivos y contingentes (Sayyid y Zac, 1998: 260). Por ello, lo que se toma generalmente por una "realidad objetiva" es realmente el resultado de una construcción discursiva y social. En este sentido, el discurso lo que nos provee de "un punto de vista" que nos permite describir la "totalidad de la vida social”, y que hace inteligible el mundo y nuestra experiencia (Laclau, 1993:433, 435). Una de las dificultades de la TDPP es que puede generar extrañeza en el lector, quien frecuentemente tiende a confundir la noción de discurso del lenguaje común con este significado más bien técnico. Lejos de reducir el campo de la discursividad al habla o incluso al "lenguaje en uso" -como hacen muchos sociolingüistas- para la TDPP la

\footnotetext{
${ }^{6}$ Laclau y Mouffe (2010) utilizan, indistintamente, las categorías formación discursiva, campo discursivo y discurso. A veces Laclau $(1993,2000,2003,2008)$ también utilizó los términos estructura, orden simbólico o sistema de diferencias.

${ }^{7}$ Incluso autores sofisticados como Norman Geras (1987) se han equivocado en este punto. Para una respuesta ver Laclau y Mouffe (2000).
} 
categoría de discurso se refiere al campo de los significados o al horizonte de sentidos que precede y hace posible cualquier "percepción, pensamiento o acción” singular (Ibíd.).

Si bien son varias las consecuencias que se derivan de esta concepción de discurso, tres revisten especial importancia para nuestro análisis del mural MVN. Primero, que para la TDPP todo evento, identidad u objeto empírico -incluido un objeto cultural como MVN- se constituye como un objeto discursivo. Es en el marco de un discurso que adquiere significado. De manera similar, cada tema, subtema u objeto del mural debe también ser leído en el contexto general del discurso de MVN. Segundo, que esta concepción de discurso supera y hace inútiles las distinciones entre prácticas discursivas y no-discursivas, entre lo visual y lo lingüístico (así como entre lo lingüístico y lo extralingüístico). Tercero, así como es cierto que el significado de todo objeto dependerá de su contexto discursivo, también es cierto que a un mismo objeto se le pueden conferir diferentes significados por parte de distintos discursos. Para el constructivismo radical de la TDPP, el significado de un objeto o una identidad es contingente al discurso que lo significa. Si lo dicho anteriormente es cierto, también la identidad de los agentes sociales y la sociedad como totalidad serían contingentes y

“... carecerían de esencia, y sus regularidades consistirían tan sólo en las formas relativas y precarias de fijación que han acompañado a la instauración de un cierto orden. A partir de este punto, parecía abrirse la posibilidad de elaborar un nuevo concepto de articulación fundado en el carácter sobredeterminado de las relaciones sociales" (Laclau y Mouffe, 2010: 134-135).

\section{Articulación y Hegemonización Discursiva}

Basándose en varias corrientes del pensamiento filosófico contemporáneo (especialmente en Heidegger, Wittgenstein y Derrida) los teóricos de la TDPP han insistido en la imposibilidad de fijar significados últimos. Ahora bien, esta imposibilidad de fijación última del sentido implica que al menos alguna clase de "fijaciones parciales" 
se vuelven necesarias. De lo contrario, "el flujo mismo de las diferencias sería imposible", pues incluso "para diferir, para subvertir el sentido, tiene que haber un sentido" mínimamente establecido. ¿Cómo logramos ese mínimo de fijación de los significados? La respuesta se haya en el proceso de significación, o en el vocabulario de la TDPP, en la articulación discursiva o, simplemente, articulación. En su sentido más general, el concepto de articulación se refiere a la práctica de construcción, dación y negociación de significado. En fechas más recientes, Laclau ha señalado que éste es un proceso retórico, y que expresa la primacía política y discursiva en la constitución de la realidad social (Laclau 2014). En términos abstractos, se puede señalar que la articulación es una práctica de combinación de elementos significativos que se lleva a cabo en un dominio de significación heterogéneo, amorfo y potencialmente infinito llamado campo de discursividad (Laclau y Mouffe, 2010:151). Laclau y Mouffe (Ibíd: 142-143) definen articulación como "toda práctica que establece una relación tal entre elementos, que la identidad de éstos resulta modificada como resultado de esa práctica". La articulación enlazaría elementos dispersos y los transformaría en momentos pertenecientes a una cadena de significantes que fija parcialmente sus significados. Una cadena de significantes no es otra cosa que un discurso. Es en este sentido que se puede afirmar que "[e]l discurso se constituye como intento por dominar el campo de la discursividad, por detener el flujo de las diferencias, por constituir un centro.” (Ibíd: 152) El mecanismo concreto que permite reducir el potencialmente infinito flujo de la semiosis es la articulación, entendida no como una simple combinación de elementos equivalentes, sino como una operación de anclaje en la que algunos significantes privilegiados -que denominan puntos nodales- fijan tendencialmente las relaciones con otros elementos (momentos en el lenguaje de la TDPP) y sus significados. Ya en Hegemonía y Estrategia Socialista, Laclau y Mouffe mostraban la influencia de Lacan (Ibíd: 152-153).

Los puntos discursivos privilegiados de esta fijación parcial los denominaremos puntos nodales. (Lacan ha insistido en las fijaciones parciales a través de su concepto de points de capiton, es decir, de ciertos significantes privilegiados que fijan el sentido de la cadena significante. Esta limitación de la productividad de la cadena significante es la que establece posiciones que hacen la predicación posible —un discurso incapaz de dar lugar a ninguna fijación de sentido es el discurso del psicótico). 
En escritos más recientes, Laclau (1996, 2005) y Laclau y Mouffe (2010) retomará este argumento por medio de su concepto de significante vacío. En esos escritos enfatizan su función de representación de la totalidad discursiva, o de la totalidad de la cadena significante. En otras palabras, el significante vacío es un punto nodal estructurante capaz de condensar y representar la totalidad. Esto requiere una singular operación de hegemonización discursiva que implica la construcción política de una universalidad tendencial. Ahora bien, en los procesos sociales concretos, junto a toda articulación frecuentemente se produce una desarticulación paralela o, incluso, entrelazada. En efecto, la articulación típicamente opera por medio de (re)descripciones retóricas en las que los elementos discursivos son desarticulados de otros discursos, para ser apropiados como momentos del propio discurso, re-contextualizándolos. De este modo, todo significante puede potencialmente ser retóricamente desarticulado y re-articulado; de lo que se deriva que los resultados de toda articulación son necesariamente frágiles, y que los significados que así se producen son siempre contingentes, inestables, parciales y temporales. Volvemos así al problema de la fragilidad de la significación - pensándola ahora, como lo hizo el último Laclau (2014), como una semiosis retórica. La significación se haya atrapada en una dialéctica inescapable entre la imposibilidad de fijar definitivamente los significados, y la necesidad de lograr una mínima estabilización de los mismos. Si los significados carecen de un fundamento último que podría garantizar su estabilidad y así asegurar la comunicación e interacción transparente, vuelve a aparecer el problema de cómo podemos comunicarnos e interactuar con regularidad.

Según Laclau (y Mouffe), la pista la da la teoría de la hegemonía de Gramsci. Ellos radicalizan su concepto de hegemonía como liderazgo (político, intelectual, moral, económico, etc.), y usan dicha intuición para comprender la significación como una operación de poder (Laclau y Mouffe, 2010). La hegemonía - o hegemonización discursiva como prefiero denominarla para distinguir esta elaboración a partir del concepto de Gramsci- es la lógica política de constitución de todo lo social (Laclau y Mouffe 2001, xii). Es por medio de la hegemonización discursiva que se logra la estabilización necesaria de los significados y del orden social. Lo social incluye tanto el orden sociopolítico como el orden simbólico, pues en la perspectiva de la TDPP ambos 
son co-extensivos. En consecuencia, es como efecto de una intervención política sobre el proceso semiótico y retórico que se produce la significación y el orden social. Es en este sentido que Laclau y Mouffe (2010) afirmaron polémicamente la primacía de la política. Esta afirmación ha sido frecuentemente malentendida, como si se tratase de una nueva forma de determinismo -a la vez idealista y anti-materialista- de la actividad política sobre la sociedad (Geras, 1987). Pero Laclau y Mouffe no piensan en la primacía de la política como una forma de determinación de la sociedad desde la política, entendida ésta última como un campo diferenciado de actividad humana. Contrario a toda forma de determinismo e idealismo, la TDPP postula un realismo radical y una nueva forma de materialismo, en el que la significación pasa a ser concebida como un proceso político, pues admite la influencia del poder en todo proceso de significación (Laclau y Mouffe, 2000). En definitiva, se trata de una lógica política que opera en toda semiosis social.

Laclau (2005: 402) desarrolló recientemente en términos algo más detallados su concepción del proceso de significación o articulación, recurriendo al psicoanálisis lacaniano:

“... si considero que la retórica es ontológicamente primaria en explicar las operaciones inherentes a la construcción hegemónica de la sociedad y las formas que ésta adopta, considero que el psicoanálisis es el único camino válido para detectar las pulsiones que operan detrás de esta construcción; es, por lo tanto, el acercamiento más fructifero para la comprensión de la realidad humana."

El aporte del psicoanálisis a la comprensión de la significación tiene que ver con la relativa estabilidad que logran los significados, pues es la dimensión afectiva o libidinal la que permite explicar la seducción y el apego que generan ciertos significados: 
“... lo que la retórica puede explicar es la forma que adquiere el investimiento sobredeterminante, pero no la fuerza que explica el investimiento como tal y su perdurabilidad. Toda sobredeterminación requiere no sólo condensaciones metafóricas sino también investimientos catécticos. Es decir que algo que pertenece al orden del afecto tiene un rol primario en la construcción discursiva de lo social. Freud ya lo sabia: el vínculo social es un vínculo libidinal. Y el afecto [...] no es algo agregado a la significación sino algo consustancial a ella. (Laclau 2008: 402; énfasis en el original).

La lógica política de la significación que constituye lo social, debe ser completada con esta dimensión afectiva. Es esta la que explica que algunos significantes sean investidos (catectisados). Así, junto a las categorías de punto nodal -y su función estructurante- y de significante vacío -y su función de representación de una totalidad (imposible)-, habría que agregar una categoría que cumpla una función equivalente al object petit a lacaniano, que al condensar la energía libidinal se configure como un significante de otro orden. ${ }^{8}$

Los conceptos de articulación y la hegemonización discursiva son relevantes en los estudios del mural MVN pues ayudan a comprender la lógica que estructura su discurso visual, y el anclaje de sus heterogéneos significantes como parte de una totalidad significativa coherente.

\section{Antagonismo y Dislocación}

A partir de la década de 1990, Laclau introduce la idea de dislocación, con la que reelabora su concepción del antagonismo, para referirse a una fundamental dimensión de negatividad sin la cual no era posible dar cuenta de las limitaciones y fallas de todo discurso y de la incompletud de toda identidad (Laclau y Mouffe, 2010; Laclau 2000,

\footnotetext{
${ }^{8}$ Este proceso de sublimación es más cercano al sentido hegeliano de lo sublime, que al sentido freudiano de la sublimación. Al respecto, ver también Žižek (1992).
} 
2014). En una serie de conferencias dictadas en Santiago de Chile, Laclau (1997: 26) recordó que

“... fue en Nuevas reflexiones sobre la revolución de nuestro tiempo [1990], que intenté desarrollar una noción de negatividad sobre la base de profundizar el momento de dislocación anterior a toda forma de organización discursiva, o de superación discursiva, o de sutura discursiva de esa dislocación."

Para Laclau, la unidad de todo discurso, así como la de toda identidad, no está dada por su núcleo de elementos positivos, sino por una red de relaciones con su exterioriad. Los conceptos de antagonismo y dislocación se refieren precisamente a esta dimensión de negatividad y exterioridad que es constitutiva de toda objetividad y que, no obstante, a la vez revela sus límites. Dicho de otro modo, para la TDPP, las identidades y los discursos se constituyen en torno a sus límites.

Paradójicamente, antagonismo y /o dislocación apuntan a una dimensión constituyente de toda objetividad (Laclau 1990, 1995, 2014). Parece ser que Laclau se inspiró principalmente en Derrida para referirse al exterior constitutivo o a una exterioridad constituyente, y en Lacan para concebir el límite de la objetividad como Lo Real, es decir, como aquello que es imposible de ser significado y, en ese sentido, como aquello que se resiste a ser controlado (Derrida, 1991: 63; Lacan, 1991: 66-67; Evans, 1996 y Stavrakakis, 1999). Laclau (1990: 180) señala al respecto:

“... el antagonismo es la disrupción de un sistema de diferencias, de un universo simbólico, por parte de un "exterior" que lo niega —lo real, en el sentido lacaniano-, que le impide constituirse plenamente." 
Desde esta perspectiva todo discurso o identidad se haya "dislocada" "en la medida en que depende de un exterior que, a la vez que la niega, es su condición de posibilidad." (Laclau 1990: 55) Es en este sentido que los “efectos de la dislocación" son aparentemente paradójicos, pues si bien ellos “amenazan” las identidades y los discursos, también están en la base de su constitución (Ibíd., 55). ¿Pero qué ha impedido en la teoría social una mayor apreciación de esta dimensión de negatividad que es constitutiva de toda objetividad?

En su célebre "Carta a Aletta”, Laclau (Ibíd., 173) afirma sintéticamente que el problema se halla en la "metafísica de la presencia" que permea el pensamiento social occidental. Es necesario superar la metafísica de la presencia, cuyo correlato es la ilusión de inmediatez con la que se construye la percepción cotidiana de la realidad y el sentido común que piensa la realidad como directamente accesible (Cuevas, 2015). Es esta ilusión de inmediatez la que ha impedido concebir adecuadamente los límites de la objetividad social, problema que la TDPP aspira a superar:

"El marxismo, del mismo modo que la mayor parte de la tradición sociológica, se basaba en la afirmación del carácter objetivo de lo social. En este sentido, el marxismo está perfectamente enraizado en la tradición intelectual de la "metafísica de la presencia". El punto central de nuestro "posmarxismo" consiste, por el contrario, en negar la objetividad de cualquier tipo de sutura o cierre final, en razón de la negatividad inherente al "exterior constitutivo" (...) (Laclau, 1990: 173).

A diferencia de las sociologías del conflicto, para la TDPP la experiencia de dislocación y antagonismo se manifiesta empíricamente en los conflictos y luchas sociales, pero en tanto dimensión de negatividad constitutiva de toda objetividad social, el antagonismo y la dislocación están siempre presentes en toda identidad o discurso aunque en ocasiones sea de manera sólo latente. En este sentido, antagonismo y dislocación se refieren a una situación más amplia y básica que una situación de conflicto social. Se trata de categorías ontológicas que describen la limitación, incompletud, o falla 
estructural de toda formación de identidad o discurso. En términos algo más concretos, se puede afirmar que antagonismo y/o dislocación nombran aquello que amenaza la existencia de un discurso o una identidad, aquello que no le permite desarrollarse en plenitud, o aquello que existiendo "por fuera" de sus límites, se expresa internamente de alguna manera. Esta intuición fundamental es muy importante para el análisis cultural en general, y lo es también de manera específica para el mural MVN. Antagonismo y dislocación se expresan de variadas maneras en MVN, pero por el momento mencionaremos 3. La dislocación remite a un límite del relato visual identitario de MVN; a una marca traumática que señala su incompletud; y a la imposibilidad de imponer una sutura discursiva que cierre la interpretación de la identidad y la historia nacional.

Como sostendré en las próximas secciones, la TDPP es útil para el análisis cultural debido a que no sólo admite, sino que además explora productivamente la tensión entre lo político, o el antagonismo, y la política hegemónica, o la lucha entre proyectos políticos por imponer tanto una sutura discursiva como un orden hegemónico. Desde esta perspectiva, cualquier práctica, el arte incluido, puede ser politizada porque la dimensión del antagonismo, lo político, no tiene un lugar específico en la sociedad y puede manifestarse potencialmente en cualquier relación (Mouffe, 2001, 2013). Por tanto, la distinción entre las prácticas políticas y no-políticas -incluyendo prácticas artísticaspierde su sentido. Al respecto, Mouffe señaló en una oportunidad que:

"No se puede hacer una distinción entre el arte politico y el arte no politico, porque toda forma de práctica artística, o contribuye a la reproducción del sentido común dado -y en ese sentido es político- o contribuye a su deconstrucción o crítica. Toda forma de arte tiene una dimensión politica" (Mouffe, 2001: 100).

Como veremos, este es justamente el nudo problemático de MVN, que manifiesta cierta indeterminación. Por una parte, expresa una versión de la identidad y de la historia de Chile que aspira a producir una clausura discursiva que intenta despolitizar la historia de sus conflictos por medio de la articulación y anclaje de todos los significantes visuales 
con una serie de ideas del campo semántico de la unidad, la cohesión social y la reconciliación. Por otra parte, también expresa una versión distinta cuyo centro es la afirmación de la división, del trauma irreductible, de la pluralidad de discursos antagónicos, y de la consiguiente apertura y contingencia que necesariamente tendría todo relato histórico y toda narrativa sobre la identidad nacional.

Los Análisis de Memoria Visual de una Nación.

El mural MVN puede ser visto como una representación visual de la identidad de la nación chilena, su memoria y su historia. Este ambicioso mural incluye la representación de la prehistoria y los pueblos ancestrales que habitaron el actual territorio chileno, el descubrimiento y la colonia, la independencia y la formación de la república, y varios de los procesos más sobresalientes de la contemporaneidad. Junto a este tema central -la identidad nacional y la memoria colectiva de la historia nacional- existen subtemas, tales como las fuerzas de la naturaleza; paisajes reales y de fantasía; la poesía chilena; el océano; el encuentro de culturas; lo popular; y los conflictos traumáticos de la historia republicana. El mural expresa también admiración por el humanismo mediante el uso de la figura humana. MVN es un mural audaz porque evita los lugares comunes y no cede a la tentación de presentar una versión edulcorada de la historia de Chile centrada en la glorificación de sus héroes y proezas. Tampoco es una yuxtaposición de clichés, ni un intento de sostener un mito patrio acerca de la coherencia cultural de la nación. Para Toral, la identidad nacional chilena no es sólo el resultado de valores, experiencias y orígenes compartidos. Igual de importantes son las experiencias que dividen, antagonismos, conflictos, y los traumas no resueltos. En efecto, Toral evita representar la identidad nacional como una entidad coherente basada en valores compartidos que cementan la sociedad —una visión común no sólo en el pensamiento social conservador - Toral parece intuir que la identidad nacional es un constructo histórico que se va formando tanto con elementos comunes, como también sobre la base de conflictos, traumas y divisiones definidas por antagonismos. 
Desde la TDPP, una identidad cultural nacional puede ser comprendida más cabalmente como una combinación de elementos y valores compartidos, con antagonismos y temas de preocupación de carácter divisivo. ${ }^{9}$ Siguiendo al psicoanálisis lacaniano, Laclau $(1994,2005)$ consideró que la identidad está constitutivamente dividida porque se basa en un vacío o falta originaria. ${ }^{10}$ Toral parecía compartir esa intuición cuando declaró que Memoria Visual de una Nación:

“... representa escenas que dividieron a los chilenos durante su historia; acontecimientos violentos y sangrientos, las trágicas divisiones que nosotros sus descendientes- hemos heredado como ciudadanos de una tierra común en que debemos vivir en paz." (Toral, 1999a)

Laclau adhiere a la concepción lacaniana del sujeto de la falta para dar cuenta del sujeto antes de la subjetivación: "uno debe identificarse con algo porque hay una falta de identidad originaria e insalvable" (1994: 3). La falta en el núcleo de la identidad tiene que ser llenada a través de procesos de identificación. ¿Qué ofrece un relato visual como el de MVN? Basándose en una acuciosa investigación sobre la historia de Chile, Toral ofrece en MVN una superficie de discursividad y una narrativa visual que contiene un conjunto de momentos discursivos de carácter simbólico o emblemático que son capaces de interpelar/identificar a los chilenos.

\footnotetext{
${ }^{9}$ Archer (1997) ha criticado las concepciones monádicas y "consensuales" de cultura. Laitin (1988) acuñó el término "puntos de preocupación" (points of concern), con el cual quiere referirse los problemas sociales que, aunque conflictivos, parecen constituir una tema o asunto de interés público de permanente preocupación para el conjunto de la sociedad. Por su parte, la noción de antagonismo de Laclau y Mouffe (2010; véase también Laclau sobre antagonismo y dislocaciòn, 1990, 2005, 2014) nos ayuda a entender la formación de identidad como un proceso polémico que requiere demarcaciones y fronteras (Laclau 1990, 2005).

${ }^{10}$ Este argumento psicoanalítico se remontan al trauma de la pérdida primordial de la abundancia original de la unidad con la madre (Fink, 1995). Sin embargo, hay que ser cautelosos al aplicar esa idea al análisis social, porque "pérdida primigenia" en sí misma puede considerarse un mito, producido por la castración/alienación que se produce al entrar en el orden simbólico, y no un momento de origen o primigenio.
} 
Aunque una nación chilena unida y reconciliada es una imposibilidad, su plenitud sigue siendo una fuerte aspiración con la que muchos preferirían identificarse. Como intenté demostrar en mi primer estudio (Cuevas 2008), MNV representa esa aspiración y la preocupación de Toral por la constitución de la nación chilena, entendida como un colectivo de personas dotadas de derechos y que comparten la misma tierra como patria (Toral, 1999a). La experiencia de nacionalidad y de identidad en Chile es especialmente traumática debido a su pasado preñado de conflictos que han dividido a la población (Huneeus 2003, Larraín 2006), y que posiblemente lo siguen haciendo hasta nuestros días. Es precisamente este aspecto de la historia nacional de Chile el que es problematizado en el panel noroeste de MVN, llamado Los Conflictos. Este panel trata específicamente sobre los antagonismos políticos y conflictos en la historia de la república chilena (Figura 1). Imágenes de dolor y sufrimiento en rojos, ocres, negros y otros colores oscuros son predominantes. Además del talento de Toral como muralista, su afinidad con la sensibilidad del expresionismo lo hacen eminentemente apto para representar dichos eventos. De hecho, su pintura contiene intertextualidaes y referencias visuales a Los Caprichos de Goya y otras pinturas del mismo artista, como El tres de Mayo de 1808: los fusilamientos en la Montaña del Príncipe Pio ${ }^{11}$, como se evidencia en la composición de la sección sobre la ejecución de Portales por el pelotón de fusilamiento. ${ }^{12}$ De manera similar, Guernica de Picasso y a la película de Eisenstein de 1925, El Acorazado Potemkin, son citados en el fresco La Masacre de Santa María de Iquique. También hay una posible conexión con pintores neo-expresionistas como Helmut Middendorf y sus imágenes de ciudades bombardeadas ${ }^{13}$ — particularmente en el friso 1973. Bombardeo de La Moneda. Otra referencia son los murales y obras tempranas del pintor ecuatoriano Oswaldo Guayasamín, con su énfasis en sentimientos profundamente humanos como el sufrimiento y la ira - por ejemplo en sus colecciones de caras de expresiones desgarradoras y manos crispadas. Por último, pero tal vez menos importante, hay conexiones con la película de 1927 de Fritz Lang, Metropolis en el friso Vida y muerte en las minas de carbón, donde los trabajadores explotados y alienados son representados de una manera que recuerda al filme (Figura 1).

\footnotetext{
11 Aquí considero al expresionismo como una sensibilidad artística en lugar de un movimiento de vanguardia.

${ }^{12}$ Diego Portales fue un importante ministro. Es visto como el político que creó las condiciones de orden, estabilidad y progreso en la república chilena durante el siglo XIX.

${ }^{13}$ Ver por ejemplo a su Flugzeug, Traum, Kopf (1983).
} 
El panel Los Conflictos ensambla elementos discursivos y símbolos de diferentes y a veces contradictorias narrativas ideológicas. Esta clase de ensamblajes ideológicos internamente heterogéneos han sido estudiados por Laclau, quien desarrolló su teoría acerca de la arbitrariedad de los significantes y la articulación a partir de la observación de estas aparentes paradojas, contradicciones y anomalías lógicas de las ideologías y los discursos (Laclau 1986, 1990, 2005, Laclau y Mouffe 2010). Por una parte, Toral se refiere en MVN al fusilamiento del Ministro conservador del siglo XIX Diego Portales. La forma en que Portales está representado, sus dimensiones, postura hierática y la presencia a su lado de una fuerza espiritual sugieren su naturaleza superior. La historiografía tradicional retrata a Portales como el ideólogo de la así llamada República conservadora (Edwards, 1936; Vial, 1981-1987). Junto a esta, MVN también representa episodios centrales para historiografía marxista y anti-oligárquica (de Ramón 2003, Villalobos, 1980; Vitale, 1993-1998; Vitale et al., 1999), como son: la matanza masiva de nativos en el sur de Chile (Julius Popper y de los mineros del salitre y sus familias en el norte del desierto de Atacama en Santa María de Iquique, a la explotación inhumana en las minas de carbón y a la persecución política bajo la Ley Maldita, que proscribió al Partido Comunista y fue usada para perseguir a líderes de la izquierda. La referencia a la guerra civil de 1891 y el suicidio del Presidente Balmaceda ${ }^{14}$ es más ambigua, ya que estos eventos han sido articulados tanto por las narrativas de la elite como por la antioligárquica. ¿En qué serie de eventos debe ser ubicada la representación del bombardeo de La Moneda, titulada 1973: el bombardeo de La Moneda? Desde mi punto de vista, en la serie de narrativa anti-oligárquica. ${ }^{15}$ ¿Pero sería acaso inequívoca esta interpretación del bombardeo de La Moneda?

\footnotetext{
${ }^{14}$ La Guerra Civil de 1891 fue un conflicto definitorio en la historia chilena. El proyecto nacional del presidente Balmaceda chocó con intereses organizados en el Congreso. Las fuerzas armadas se dividieron y un segundo gobierno fue establecido en el norte. El partido de Balmaceda fue finalmente derrotado. Aislado, cometió suicidio en lugar de rendirse a sus oponentes.

${ }^{15}$ De hecho, uno de los participantes del análisis de recepción, L, una persona bien educada en el campo de la historia, era muy consciente de esta selección de acontecimientos, que él consideró como "popular" (populista). Sin embargo, como se ve aquí, los otros dos participantes consideraron la sección particular sobre el bombardeo de La Moneda menos controversial.
} 
La Moneda en Llamas: la multivocidad de los significantes, la pluralidad de los discursos y la imposibilidad de una sutura discursiva.

En mi primer estudio de MVN, el análisis de la representación del bombardeo de La Moneda fue central. Mi argumento fue que la representación del golpe de estado de 1973 en Chile no tiene un significado inherente y objetivo. En mi experiencia cotidiana, la que presumo es compartida por muchos compatriotas, me he encontrado con múltiples y a menudo contradictorios significados otorgados por diferentes clases de personas, los que les son conferidos por medio de prácticas discursivas de articulación que se disputan su significado. Como se trata de una construcción discursiva, tiene en tanto evento un significado contingente, polémico, como un significante flotante (Laclau 1990, 1995, 2005, Laclau y Mouffe 2010). Para demostrar la contingencia de su significado, analicé representaciones fotográficas y pictóricas del bombardeo de La Moneda en sus contextos discursivos.

El sentido común asume, tal vez erradamente, que las fotografías, debido a su carácter icónico, tienen un significado unívoco y aproblemático. Como sostiene Fiske (1990), la imagen fotográfica tiende a eludir la contingencia del significado. Su realismo parece garantizar su objetividad como un espejo de la realidad, reflejándola fielmente, sin intrusión. En realidad, sin embargo, el texto fotográfico está entrelazado en intertextualidad, por lo que su significado no está fijado. El significado de la fotografía es contingente, abierto a la interpretación y, por lo tanto, vulnerable a la intervención política. En suma, la fotografía no tiene un significado verdadero y único. Toda pretensión de verdad con respecto a la interpretación de la imagen fotográfica no sería más que un movimiento estratégico, un intento de hegemonizar su significado. Como afirma Stuart Hall (1991: 152-3:

“... la búsqueda de su "Verdad esencial” -un momento fundacional y originario de significado- es una ilusión. Las fotografías son esencialmente multiacentuadas en significado. Tal momento natural previo de significado verdadero, intocado por los 
códigos y relaciones sociales de producción y lectura, y trascendente del tiempo histórico, no existe."

Las intervenciones políticas sobre imágenes y fotografias generalmente tratan de fijar sus significados anclándolas en cadenas discursivas más amplias. Esto es exactamente lo que ha sucedido con las imágenes del bombardeo e incendio de $\mathrm{La}$ Moneda. Estos han sido interpretados de maneras muy diversas. Como consecuencia, a la misma imagen (Figura 2) se le dan títulos y encabezados por diferentes personas y grupos que abiertamente se contradicen entre sí. El sitio web de una Organización chilena de derechos humanos ubicada en Gran Bretaña publicó la misma imagen bajo el título: "11 de septiembre: golpe de estado." Y a ello el mismo sitio web agregaba:

"En 1973 los militares encabezados por el Augusto Pinochet, derrocaron al gobierno democráticamente elegido en Chile, del Presidente Salvador Allende, imponiendo una dictadura militar hasta 1990" (Memoria Viva, http://www.memoriaviva.com/) Una interpretación muy diferente de la misma imagen es proporcionada por la Liga Chilena Anticomunista: "La Moneda en llamas: la única manera de liberar a la Nación del marxismo" (la Liga contra-comunista chilena, http://www.geocities.com/CapitolHill/Congress/1770/11-september-1973.html, 26.07.2006).

En conclusión, una imagen fotográfica, a pesar de su aparente carga de objetividad, puede interpretarse de diferentes maneras debido a que el evento real representado en la imagen es descrito y se define de manera distinta en diferentes discursos. En relación al tema en cuestión, podemos decir que el evento del 11 de septiembre de 1973 está discursivamente construido, ya sea como el trágico fin de la democracia chilena, o como su liberación del marxismo. El significado del 11 de septiembre de 1973 o de sus representaciones en imágenes o pinturas depende de la función estructuradora del discurso que lo significa. ¿Cómo opera la función estructuradora del discurso en este caso? Las interpretaciones contradictorias de la fotografía del bombardeo de La Moneda 
son posibles por la apertura de los signos a una variedad de articulaciones discursivas (Evans y Hall, 1999; Hall, 1991). Así, cada discurso funciona como "un punto de vista" que le otorga un significado a la realidad, la hace inteligible y nos permite describirla (por cierto, de una manera entre varias posibles) (Laclau 1993: 433-435). Me pregunté entonces si la representación de La Moneda bombardeada en MVN sería también interpretada en varios sentidos distintos, como sucedía con sus imágenes fotográficas.

\section{Bombardeo de La Moneda, según Mario Toral}

En mi opinión, la naturaleza icónica de la imagen representada en el friso 1973. Bombardeo de La Moneda -más figurativa y realista que otras del panel Los Conflictospodría determinar o restringir algo más su significado. Sumado al título (1973. Bombardeo de La Moneda) y al tono general de la serie anti-oligárquica de eventos representados en el panel, la representación del bombardeo de La Moneda parecería menos abierta. Este edificio es el corazón del poder ejecutivo en Chile y simboliza el núcleo de las instituciones democráticas en la tradición presidencial. Por ello, es fundamentalmente una metáfora del quiebre de la democracia.

Por otro lado, el friso, al mismo tiempo que fundamentalmente figurativo, no es del todo realista. En efecto, varias formas de distorsión de la imagen son articuladas con el propósito de aumentar el dramatismo y, en cierto modo, de limitar la polisemia potencial de la imagen. Veamos cómo operan ambas estrategias -representación realista y distorsión- de manera copulativa.

El friso que se refiere al golpe de estado de 1973 y al quiebre de la democracia está significativamente ubicado en una posición central en el panel Los Conflictos (ver Figura 1). La representación icónica del bombardeo e incendio del Palacio se inspira claramente en las históricas imágenes de televisión y fotografías. En ese primer estudio postulé que MVN no representa el evento golpe de estado de 1973 en sí, sino que una versión pictórica de La Moneda bombardeada y en llamas que lo simboliza. La 
composición del friso nos recuerda al evento fílmica y fotográficamente representado. Sus imágenes han sido profusamente difundidas en reportajes y documentales bien conocidos, con las que generaciones de chilenos han convivido, de manera por cierto problemática, desde 1973. ${ }^{16}$ Aunque los hubiere presenciado personalmente, es evidente que la representación de Toral no está basada (o no lo estaría) en recuerdos personales del bombardeo a La Moneda, sino en imágenes ampliamente diseminadas y bien conocidas. En mi opinión, esto es coherente con la lógica completa de su mural, que se deriva y fortalece de la memoria colectiva en lugar de los recuerdos personales e íntimos del artista. Es decir, se trata de un evento que marca la cultura chilena contemporánea, que es a la vez polémico y mediatizado. ${ }^{17}$

Este punto es crucial, porque hace a la representación de los acontecimientos de 1973 algo bien diferente de las representaciones de otros eventos del mural, de los que carecemos de imágenes fotográficas o fílmicas y que están más lejanos en el tiempo de la imaginería que puebla la cultura de las generaciones más actuales. Tal vez por ello ocurre que la mayoría de los otros eventos conflictivos representados se encuentran en espacios imaginarios, muy rarificados o distorsionados por la imagen pictórica y sus posibilidades expresivas. ¿Acaso la estrategia representacional diferente de 1973. Bombardeo de La Moneda es un intento de positivizar y objetivar la construcción discursiva del quiebre de la democracia de 1973, con el fin de evadir la potencial polisemia de toda representación simbólica?

Junto con este intento de objetivación del bombardeo de La Moneda, hay aquí una cierta repetitividad (iterability) operando. La mirada atenta revela que la representación de las imágenes fotográficas y documentales popularizadas es torcida en la representación

\footnotetext{
${ }^{16}$ Una encuesta de 2003 (Fundación Futuro, 2003) muestra que el golpe de estado sigue siendo el evento más definitorio de la historia chilena a través de las generaciones. Sin embargo, para las generaciones más jóvenes otros eventos -como el plebiscito de 1988 o la detención de Pinochet- se consideraron más importantes. Este efecto marcador del golpe de estado de 1973 también es enfatizado por los participantes. Más aún, mientras viví en el extranjero me he dado cuenta de que estas imágenes también han sido utilizadas por los medios internacionales (véase Strasma, 2003).

${ }^{17}$ En este sentido, las reflexiones sobre la mediación visual de nuestras experiencias en las sociedades de reproducción mecánica -y ahora digital- también pueden aplicarse a este caso (i.e., Debord 1977).
} 
pictórica, aunque las primeras sean del todo reconocibles a través de un remanente mínimo del significado (ver Culler, 1998, sobre repetitividad). Permítaseme descomponer algunas de estas variaciones, comenzando con la perspectiva. El panel presenta una vista frontal de una sección de la fachada. La escala también está modificada. La imagen en el mural muestra detalles dramáticos del bombardeo en primer plano en lugar de la vista panorámica habitual de explosiones, humo, y polvo vistos desde un ángulo lateral. Otra intervención tiene que ver con la representación de los aviones caza. No hay ninguna representación fotográfica que muestre a los aviones y al edificio juntos, porque la distancia entre los dos era demasiado grande. Sin embargo, las imágenes documentales de los caza aproximándose a la zona cívica del centro de Santiago han sido muy difundidas. Aquí, el edificio es brutalmente atacado por aviones oscurecidos, asemejándose a halcones negros o relámpagos. Una tercera variación es la dramatización de la imagen a través de la caída del asta de la bandera. La bandera cayendo simboliza el dolor de la nación chilena y el colapso de su democracia.

Además de estas intervenciones, también debemos considerar el papel simbólico de las manos que rodean la representación del bombardeo de La Moneda. La mayoría de ellas están unidas en oración o estrechando a otras manos. Las manos unidas apelan a un código religioso para expresar la esperanza de reconciliación nacional. La mano con el dedo levantado se remonta al famoso y ambiguo San Juan Bautista de Leonardo da Vinci y a otras pinturas religiosas en las que el personaje principal apunta al misterio del Cielo. Otro símbolo cristiano es el de la mano de Dios. ${ }^{18}$ Además, el gesto de la mano de la izquierda está claramente inspirado en las típicas representaciones del Señor de la Divina Misericordia. El mural se refiere a la conflictiva realidad chilena y a la división fundamental de su pueblo y, al mismo tiempo, a la tarea universal de construir una civilización caracterizada por la paz y la felicidad. La representación visual de la historia de Chile en MVN se aleja de toda expresión utópica de homogeneidad social, y no rehúye expresar los conflictos traumáticos de la historia de Chile. Como ha señalado el propio Toral (1996: 160-161):

\footnotetext{
${ }^{18}$ La figura de la Mano de Dios tradicionalmente se ha utilizado en la iconografia cristiana para la representar al Dios Padre, sus acciones, la creación, milagros y su presencia en la historia de la humanidad.
} 
"En el panel norte "Pared de los Conflictos" hay escenas de acontecimientos que han dividido a los chilenos a través de su historia, situaciones en que se ha derramado sangre, sangre de conflictos que sus descendientes han heredado y que nos ha separado como ciudadanos. (...). Ojalá no hubiera tenido que pintar estas escenas, pero si estas pinturas respetan su título "Memoria visual de una nación", es un deber moral hacerlas presentes. No repitamos errores pasados."

El reconocimiento de los conflictos es una condición lógica necesaria para la emergencia de un discurso acerca de la reconciliación nacional. La fantasía de una reconciliación nacional parece por tanto ser junto con los conflictos, otro de los temas principales de esta sección. La nación reconciliada es evocada a través de su ausencia en las imágenes de dolor y conflicto. Más aun, las representaciones de estos dolorosos hechos de la historia chilena pueden leerse como una narrativa nacional que trasciende las particularidades de cada evento cuando oponemos a las divisiones que evocan el escenario imaginario de un Chile reconciliado. Pero, se expresa de manera explícita como un deseo o una esperanza en los gestos de manos estrechándose en un saludo o en otras encomendando sus ruegos a Dios.

Aquí encontramos un concepto cuasi-religioso de reconciliación sociopolítica. En contraste con el significado estrictamente religioso de reconciliación, que también se basó en la idea de unidad, la reconciliación sociopolítica significa principalmente paz como un estado en que el antagonismo es sublimado o superado. Esto no es un accidente o una representación idiosincrática de Toral. Tanto líderes religiosos (p. ej.: Monseñor Silva S.D.B., 1986) como políticos (p. ej.: Aylwin 1992; Foxley, 2003) utilizaron ampliamente símbolos religiosos y figuras de unidad y reconciliación cuando se refirieron a la redemocratización de Chile durante la década de 1980 y 1990. 
Las manos de Los Conflictos, en tanto símbolos significantes de reconciliación y consenso, funcionan como puntos nodales (Laclau y Mouffe, 2010) o significantes vacíos (Laclau, 1996, 2005) que estructuran y unen elementos que de otra forma estarían aislados y se mantendrían como elementos controvertidos, transformándolos así en momentos del discurso general sobre la reconciliación nacional. Las manos se constituyen en puntos nodales, símbolos de la reconciliación nacional, la paz social y el consenso sociopolítico. Como símbolos privilegiados, significantes maestros de la secuencia significativa del panel Los Conflictos, las manos son momentos clave en la articulación que, recordemos, consiste en "la construcción de puntos nodales [y significantes vacíos] que fijan parcialmente el sentido" (Laclau y Mouffe, 2010:154, adición mía entre []). En este caso particular, las manos funcionan como significantes vacíos/puntos nodales que anclan las otras imágenes dispersas del panel. Se construye así, a partir de la aparente dispersión de cuadros dolorosos, una secuencia narrativa acerca de la reconciliación nacional que está respalda por una fantasía particular: la fantasía de la integridad, totalidad y plenitud de la comunidad nacional. ${ }^{19}$

A pesar de la voluntad de reconciliación que atestigua la sección Los Conflictos, su inauguración demostró ser un evento controversial. Tenemos que recordar que tuvo lugar a principios de 1999, en una coyuntura de polarización en torno a la detención de Pinochet en Londres. La inauguración del mural se encontró con virulentas críticas, especialmente de varios líderes de derecha (Cuevas 2008, 2015a). Las razones de esta controversia superaron con creces el caso Pinochet. El mural suscitó recuerdos de tiempos terribles, en que el miedo volvía a irrumpir. El miedo había sido una condición del golpe militar, pero también fue su resultado y una justificación para la posterior consolidación de la dictadura. ${ }^{20}$ Como vimos, para algunos la dictadura militar fue una respuesta a la

\footnotetext{
${ }^{19}$ La relación entre punto nodal, significante vacío y fantasía es un área dinámica de la actual investigación para los teóricos del discurso (Glynos, 2001; Stavrakakis, 2007). Sobre la distinción entre punto nodal y significante vacío, ver Laclau (2008), donde sostiene que tienen el mismo referente pero enfatizan diferentes funciones. Mientras que el punto nodal enfatiza los aspectos de unión y estructuración, el significante vacío enfatiza la representación de una imposibilidad. Laclau no utilizó el término fantasía. Sin embargo, concuerda en que hay aspectos en común con su concepto de significante vacío (comunicación personal).

${ }^{20}$ Norbert Lechner (1990) se refirió a la "cultura del miedo". De manera similar, Silva (1999) desarrolló la idea de miedos sociales en relación a diferentes experiencias traumáticas de diversos sectores de la sociedad chilena.
} 
amenaza de una revolución y una toma del poder de los comunistas (estos eran los miedos de la derecha, las clases acomodada y, los sectores medios). El autoritarismo chileno apuntaba a poner fin a la escasez, la inseguridad, y el desorden. En consecuencia, la reconstrucción de la economía y la oferta de mercancìas, la elevación del consumo, la promoción del orden, y los valores nacionales tradicionales formaron la base por medio de la que la dictadura intentó legitimarse frente a una parte significativa de la población. Para otros, el miedo era el resultado de la dictadura y sus medidas de orden: la represión militar y la persecución política. Durante el período post-autoritario, el miedo a revivir el pasado -tanto el pasado revolucionario, como pasado dictatorial- formó el telón de fondo de la política consensual y el discurso de reconciliación nacional. Como dijo un ex Ministro de Defensa de aquel periodo, el trauma era la motivación subyacente de lo que se llamó "las lecciones de la historia." La estabilidad de la nueva democracia, la paz social y la gobernabilidad requirieron de la élite el aprendizaje de esas lecciones (Boeninger, 1997; Fernández, 1998).

Desde el punto de vista de la teoría de la formación de identidad / identificación, debemos pensar en los conflictos como expresiones de antagonismos y dislocaciones (Laclau, 1990; 1994; Laclau y Mouffe 2010). La idea de reconciliación, como también sus expresiones visuales, presupone la existencia, en un momento dado en el pasado, de una unidad que fue rota. Aunque este momento de unidad pueda ser puramente ficticio y mítico, suele tener efectos discursivos reales. Así, podemos decir que la identidad chilena contemporánea se construye no sólo sobre la base de elementos compartidos, sino también sobre la base de conflictos, divisiones, traumas y antagonismos que constituyen puntos que dividen la cultura nacional (Cuevas, 2008, 2009, 2014, 2015), que es exactamente lo que es relevado cuando consideramos la cuestión de la formación de identidad desde el punto de vista de la teoría lacaniana contemporánea (Laclau, 1994; Laclau y Zac, 1994; Stavrakakis, 2007; Žižek, 2000, 2003). En síntesis, la sociedad chilena, traumatizada por su pasado de conflictos, requiere la fantasía de una reconciliación nacional para mantenerse unida. 


\section{La recepción de 1973. Bombardeo de La Moneda}

Para explorar si la pintura de La Moneda en el mural está abierta a variadas interpretaciones conduje un estudio de recepción del mural con un número limitado de personas de diferentes opiniones políticas y diversos orígenes sociales (Cuevas, 2008). En lugar de considerar el discurso como un conjunto de declaraciones que sólo requieren el estudio de su morfología para revelar su significado, siguiendo algunos ejemplos de los Estudios Culturales británicos preferí situarlo en el contexto de los procesos de producción, recepción y reproducción de significado (Hall, 1993). Dicho de otro modo, el análisis del discurso en el campo cultural debe prestar atención no sólo a las características de los discursos empíricos bajo análisis, sino también al circuito que conecta producción y recepción. El discurso es producido por alguien, pero para alguien; es codificado, puesto en circulación y decodificado. El discurso interpela a sujetos, quienes se identifican con él si es exitoso. Pero también pueden tomarlo parcialmente, resistirlo, o ser indiferentes. Por lo tanto, mi objetivo se completó sólo al analizar los significados codificados y su recepción activa por parte de un pequeño número de espectadores.

Desde este punto de vista, la significación tiene lugar tanto en la fase de producción como en la de recepción. ¿Tuvo el discurso sobre el consenso y la reconciliación nacional, que permeó la producción cultural post-transición desde el fin del periodo autoritario, apoyo, o fue resistido por los espectadores? El panel Los Conflictos me permitió abordar la construcción de significados conflictivos sobre el proceso de democratización chilena-el quiebre de la democracia, autoritarismo y redemocratización-y de las memorias colectivas que estos procesos han producido, especialmente los recuerdos de las violaciones de los Derechos Humanos.

La imagen del bombardeo al palacio presidencial evocaba en mis participantes recuerdos y declaraciones conflictivas sobre el quiebre de la democracia, así como sobre el posterior autoritarismo. Todos los participantes asociaron la imagen con el autoritarismo y las violaciones a los derechos humanos. Efectivamente, sucede que en el 
nivel sintagmático, la combinación de imágenes alusivas a conflictos contribuye a anclar el mensaje y limitar su potencial polisémico inhibiendo la producción de nuevas lecturas (para esto, véase Fiske, 1990). En el mismo nivel metonímico o sintagmático, uno también debe mirar la combinación de elementos en la imagen (Nichols, 1985). Esta combinación — o articulación, en el lenguaje de Laclau y Mouffe—es crucial para el trabajo de significación. Por ejemplo, la articulación de los bombardeo, la bandera cayendo, el asta rota, las llamas, el edificio incendiado, son elementos que, como era de esperar, enfatizaron en mis participantes sentimientos predominantemente negativos hacia el golpe militar.

El panel en cuestión es ambiguo. Por un lado, representa valientemente temas políticos controversiales como asesinatos masivos, explotación, represión política y violencia política, y más generalmente, el quiebre de la democracia y las violaciones de los derechos humanos que tuvieron lugar en diferentes momentos de la historia republicana de Chile. Por otro lado, no logra producir una interpretación contrahegemónica radicalmente crítica de la historia chilena. Esto es así porque MVN, a través de una lectura negociada de los antagonismos sociales que han marcado la historia chilena, apoya finalmente el discurso dominante de reconciliación nacional de la elite chilena de los 1990. Esta lectura hipotética e inicial que hice del panel, se vió confirma por el hecho de que Toral aceptó retirar el que era el friso más controversial; una pieza que solo hemos podido apreciar cómo fue originalmente planeada 17 años después de la inauguración del mural.

Pero también hubo participantes para quienes las imágenes de las manos evocando paz, unidad, acuerdo, etc., no funcionaban como símbolos eficaces de reconciliación. ¿Carece este símbolo de la capacidad para articular o negociar las diferentes miradas de los conflictos de la historia chilena? Entre los dos conjuntos de imágenes -cuadros de eventos conflictivos, gestos de reconciliación de las manos- algunos de los espectadores experimentan una tensión irresoluble, una extrañeza o incluso una disonancia. Al apreciar las lecturas reales de la gente, con cierta sorpresa tuve que concluir que la que había identificado como la "lectura preferida" (Hall, 1993), que como tal es siempre 
estructurada en el polo de la producción, está lejos de ser exitosa. Después de todo, debido a que todo discurso está dislocado, toda "lectura preferida" tendrá sus contradicciones, sus propios intersticios por los que se cuelan las fallas en la representación de la identidad nacional. El estudio de la recepción del este panel Los Conflictos me probó que MVN es una obra abierta (Eco, 1999), incluso más de lo que personalmente había esperado. Este estudio de recepción hizo evidente que la interpelación suele fallar y que la producción de significado es un proceso contingente y abierto. El discurso la reconciliación nacional que se expresa en MVN está inherentemente dislocado.

1986. Martirio de Rodrigo Rojas y Carmen Gloria Quintana: la dislocación del discurso sobre la reconciliación nacional y la gobernabilidad

La publicación de mi primer estudio sobre MVN (Cuevas 2008) no consignaba una información que obtuve -pero que no había podido confirmar- acerca de un caso de censura del mural. De esto había ciertos indicios. Por ejemplo, en una entrevista publicada en revista Rocinante en 1999 (Toral, 1999a), el entrevistador consultó a Mario Toral su opinión acerca de la censura de que habría sido objeto. Sin embargo, el pintor no aclaró el caso concreto de MVN y rehuyó la pregunta relatando otro caso de censura del que fue objeto durante la dictadura de Pinochet. Sí afirmó cierta inconformidad con Metro y MetroArte (Toral no habría asistido a la inauguración de la sección poniente de MVN).

El año 2015 publiqué un segundo artículo sobre MVN; ésta vez centrado en la censura de que fue objeto el mural y acerca de las huellas que la delataban. Entre el primer artículo y este del 2015, nuevos indicios aparecieron que señalaban la veracidad de esta censura. Un primer indicio fue la instalación en el museo de la Memoria y los Derechos Humanos, inaugurado el 2010 en Santiago de Chile, de una imagen dedicada a la representación del denominado Caso Quemados, uno de los actos más terribles de la represión durante la dictadura: dos estudiantes universitarios que fueron quemados vivos por agentes de una patrulla militar por haber participado en una protesta contra la dictadura en 1986. Esta imagen correspondía al bosquejo del friso 1986. Martirio de Rodrigo Rojas y Carmen Gloria Quintana (Figura 4). 
Durante mi investigación de MVN también pude hablar con dos personas que participaron en la producción del mural que mencionaron que había un controversial friso que fue retirado poco antes de su inauguración en 1999. También me mostraron una fotografía de los avances en el friso, que parecía para mi ojo inexperto un trabajo casi terminado. ¿Por qué fue retirado este friso que formaba parte del plan original de MVN? Mis informantes me comunicaron que, sólo después de la presión indirecta del gobierno liderado por el presidente Eduardo Frei Ruiz-Tagle, Mario Toral aceptó voluntariamente retirar el friso. Se le habría planteado que el tema escogido para el friso era un símbolo poco representativo de la historia nacional, y que su contenido divisivo podía agudizar la controversia nacional sobre la suerte de Pinochet en Londres. Mario Toral, a pesar de su insatisfacción, siguió vinculado a MetroArte y nunca abordó el tema de la censura del mural en detalle. No parece fácil sacar a luz todos los aspectos de esta operación de presión y censura. Pero tampoco parece necesario hacerlo, toda vez que ya es claro que jugó un cierto rol en la construcción hegemónica que fue funcional a la política consensual de los 1990. Curiosamente, Toral decidió sustituir el polémico friso con la extraña selección de un texto que él atribuyó a Bertolt Brecht (Figura 3). El texto, que trata acerca del absurdo del progreso material incapaz de hacer a los seres humanos más felices y libres, fue ubicado bajo el friso 1973. Bombardeo de La Moneda. ¿Fue esta anómala selección una manera de hacer visible una huella de la censura? Otro hecho que me permitió confirmar el caso de censura fue la reapertura del Caso Quemados debido a la sorpresiva declaración de uno de los miembros de la patrulla militar que rompió el ominoso silencio cómplice del crimen. Producto de ello, escribí una columna de opinión en un medio electrónico que abogaba por la restitución del friso (Cuevas, 2015b). Conjuntamente, Mario Toral y un alto personero del Museo de la Memoria y los Derechos Humanos, solicitaron al directorio de Metro hacer un público relanzamiento del mural y reponer el friso.

Ahora ya es de público conocimiento que el panel Los Conflictos no incluyó en su instalación el friso 1986. Martirio de Rodrigo Rojas y Carmen Gloria Quintana, a pesar que éste estuvo prácticamente concluido y fue incluso enseñado a Carmen Gloria 
Quintana, sobreviviente del Caso Quemados. ${ }^{21}$ En su literalidad, el friso representa a los jóvenes quemados. Pero sus connotaciones son más amplias: como me lo señaló en una entrevista la propia Carmen Gloria Quintana, el friso simboliza las violaciones a los derechos humanos acaecidas durante la dictadura de Pinochet (ver Figura 5).

En mi interpretación, la censura y reemplazo del friso apuntaba a evitar controversias mayores en un momento de polarización y división nacional cuando el mundo entero prestaba atención al procesamiento del dictador Pinochet. Luego de transcurridos 16 años de su inauguración, Toral (2016) ha señalado con mayor libertad que:

No podría decir que fue una censura radical, sino más bien un propio resguardo por la inestabilidad de esos años donde Pinochet aún era comandante en jefe de las FF.AA., era una figura aún muy presente. La gente ha insistido en la polémica, pero para mí lo importante de este gesto es rescatar la justicia en abstracto, sin importar los colores políticos. Los murales son especiales porque tienen vida propia: cambian los gobiernos, cambia la gente que los ve y cambian los contextos. Un buen ejemplo es el mural de Diego Rivera en el Rockefeller Center de EE.UU. El pinta a Marx y Lenin y fue absolutamente censurado y destruido, pero luego lo reprodujo en el Museo de Bellas Artes de México, donde es una de las piezas más admiradas. Mi mural también tiene distintas lecturas según quien lo vea, eso es lo bonito y lo potente de una obra pública.

La historia de MVN y su producción evidencia que lo reprimido tiende a retornar y reemerger. La enigmática presencia de la huella de esta represión estuvo instalada por más de 15 años como un texto disonante (Cuevas 2015a). A primera vista, el texto aparece como una extraña elección para un discurso pictórico sobre la identidad nacional de Chile y su memoria colectiva. Sin embargo, éste pudo ser seleccionado de manera estratégica. Así, el texto, al mismo tiempo que permite ocultar el friso retirado, deja su huella y

\footnotetext{
${ }^{21}$ Comunicación personal.
} 
visibiliza su ausencia en $\mathrm{MVN} .^{22}$ El texto atribuido a Brecht era un remanente o legado simbólico de la censura del friso que tendría que haber representado simbólicamente las violaciones de los Derechos Humanos. La anomalía del texto se hacía evidente en su asintonía con el código visual predominante en MVN

La censura, que es una forma de represión, es sintomática de la transición chilena. Ésta ha sido descrita como un proceso inacabado, preñado contradicciones y de legados autoritarios que se derivan de su carácter transaccional (Garretón, 2008; Moulian 1997; Cuevas 2001). La reciente revelación del contenido censurado (¿reprimido?) que evoca las violaciones a los Derechos Humanos y los abusos de la dictadura de Pinochet. La representación de La Moneda en llamas, la censura del friso sobre las violaciones a los derechos humanos en dictadura, su huella - el texto de Brecht- expresan la dimensión irreductible del antagonismo en el mural MVN. En este sentido, MVN puede ser interpretada como una narrativa visual y un discurso acerca de la identidad nacional preñado de complejidades. Incluso de ambigüedades, como la ya señalada acerca de la articulación de significantes del conflicto y la división social, y significantes de la cohesión social y la reconciliación nacional.

\section{Conclusión}

Primero, MVN es una obra compleja, cuya historia demuestra que como todo objeto cultural, permanece abierta a la interpretación. Segundo, que su significación es política y refleja antagonismos y dislocaciones no resueltas. Tercero, que los conceptos de discurso, articulación, hegemonía y antagonismo elaborados por Ernesto Laclau y Chantal Mouffe son de gran utilidad para este tipo de análisis cultural.

La aplicación de los conceptos de la TDPP al análisis cultural es fructífera porque enfatiza los aspectos políticos de la producción cultural, los que son a menudo pasados

\footnotetext{
${ }^{22}$ La idea de huella es aquí tomada libremente, con ciertas licencias, de Derrida (1998).
} 
por alto. Su teorización de la semiosis no es ajena a las relaciones de poder, dado que la TDPP es en lo fundamental una teoría de la hegemonización discursiva de los significados.

En esta perspectiva, el mural MVN, así como toda producción cultural, participa de las luchas por hegemonizar el campo de significados de la identidad y la historia nacional. la hegemonía. Como vimos, la producción, apertura al público e historia reciente del mural MVN demuestra que el poder y la producción de significado no son fenómenos distantes y separados. El caso de la censura de que fue objeto MVN, y los posibles intentos por dejar una huella de la misma en el mural, hacen muy evidente la dimensión política del mural y, más generalmente, de toda la producción cultural. En términos hipotéticos, podría sostenerse que existe una economía política de la producción cultural. El esquema de financiamiento del arte público por medio de franquicias tributarias y mecanismos de colaboración público-privado puede someter al artista a importantes dependencias que, en este caso pueden haber jugado en contra de la libertad de expresión. Por otro lado, las condiciones de la democracia post-Pinochet, en que los legados del autoritarismo pervivieron por largos años, ejercían restricciones también sobre la producción cultural. ${ }^{23}$

Por otra parte, el arte parece ser un campo particularmente interesante para la aplicación de los conceptos de la TDPP. El análisis de obras de arte con fines de investigación política es también prometedor. Las prácticas culturales y artísticas con frecuencia resultan en la expresión de traumas, fantasías y ansiedades colectivas que permanecen sin expresión en otros campos. Esta es una buena razón para analizar expresiones visuales del discurso. Dicho análisis es especialmente fructífero para la exploración de la dimensión afectiva de la construcción de significados, que es frecuentemente apoyada por una estructura de fantasía. Como nos enseña el psicoanálisis lacaniano, la fantasía, aunque simbólicamente estructurada, surge del reino de las

\footnotetext{
${ }^{23}$ Sobre régimen híbrido o de democracia semisoberana en Chile, ver Huneeus (2013).
} 
imágenes, del imaginario. ${ }^{24}$ Las expresiones visuales fantasmáticas — como aquellas de Los Conflictos - facilitan el acceso a las pasiones y a los traumas involucrados en el discurso politico. ${ }^{25}$

La TDPP, a diferencia de otros constructivismos radicales, considera la construcción de significado como un proceso político que combina articulación y hegemonización. La articulación es una categoría clave de la teoría social de Laclau y Mouffe, y puede ser vista como una importante contribución a la teoría de la hegemonía. Su campo potencial de aplicación es amplio, extendiéndose más allá de los dominios de discursos y documentos políticos, hacia la arquitectura, el arte, rituales y todos los demás campos de la acción humana.

Las divisiones, traumas y conflictos que parecen desgarrar la identidad nacional chilena son de carácter constitutivo, son inevitables e irreductibles. Son síntomas de lo que en un nivel ontológico de análisis es el carácter siempre-ya-dislocado de la identidad (Laclau, 2000).

En términos de análisis sustantivo, es posible afirmar que a pesar de enfatizar el aspecto conflictivo de la historia chilena, MVN termina fomentando otra versión consensual. Una que por cierto no oculta algunas de sus aristas más oscuras de tiempos remotos, pero que tampoco rehúye de reprimir aquellos conflictos más cercanos a la experiencia de las actuales generaciones, como sucedió con la representación a las violaciones a los derechos humanos. MVN utiliza estratégicamente símbolos e imágenes

\footnotetext{
${ }^{24}$ Me refiero a lo Imaginario y lo Simbólico en el sentido lacaniano. No estoy usando el término simbólico en su sentido convencional, en el cual las imágenes simbólicas serían tomadas en el sentido de imágenes que representan algo más.

${ }^{25}$ Esto no es ajeno a la experiencia política cotidiana. De hecho, es obvio que los símbolos visuales funcionan como representaciones globales y sintéticas en las campañas electorales. Tales símbolos combinan dimensiones cognitivas y afectivas de significación política. Establecen un mapa político para los votantes (función de estructuración cognitiva), mostrando quiénes son aliados/amigos, y quiénes son los enemigos/contendientes. Sostengo que en el caso de Chile durante el período estudiado aquí, los símbolos visuales, como los que se utilizan en obras de arte públicos como Memoria Visual de una Nación, son también políticamente importante.
} 
de la reconciliación y el consenso como puntos nodales/significantes vacíos en la estructuración de significados. La eficacia de tales símbolos se basa en una estructura de fantasía, en torno a la cual circulan las imágenes y conceptos de unidad, armonía, nación, valores republicanos e identidad nacional. Estos significantes están integrados en los discursos que producen los significados de esas imágenes. Además, hay una cierta economía del goce que se basa en la fantasía de la paz social, la plenitud, la unidad y la cohesión social para apoyar estos significados de reconciliación. La representación de los conflictos y divisiones, su superación y la instalación imaginaria de un escenario de unidad nacional, describe al primero como un estado horrible e intolerable, y al último como uno deseable. De este modo, esta narrativa visual aspira a enseñar qué debemos desear como ciudadanos chilenos (Toral 1999a). Esta es una fantasía de unidad harmoniosa de la nación como un todo que conduce a la construcción mítica de una comunidad imaginada que intenta ya sea eclipsar la dimensión del antagonismo social, o reconciliarla en un escenario imaginario.

Aun así, las imágenes del mural hacen el antagonismo social visible, y lo presentan como constitutivo de la identidad y la historia de Chile. La presencia de un enemigo de la comunidad chilena está todavía presente implícitamente por sus efectos. Toda fantasía, para ser efectiva, debe acompañarse de su negativo e identificar a los agentes del mal, que frecuentemente son meros chivos expiatorios del inevitable fracaso de los sueños utópicos que, como diría Laclau (1990), adolecen de una dislocación estructural. En Los Conflictos, la amenaza al escenario beatífico de la fantasía de unidad nacional se representa explícitamente como dolor, opresión, conflicto interno, y por quienes lo causan. Este es el elemento horrífico de la fantasía de plenitud y unidad nacional -la división de la nación chilena, los eventos del pasado que separan y la posible reproducción de tales divisiones en los tiempos por venir- son irreductibles y expresan una dimensión de antagonismo insuperable. No obstante, alguna forma de solución a esta amenaza debe ofrecerse para servir de fundamento a la narrativa nacional. ¿Cuál es ésta en MVN? No otra que una representación de la reconciliación. Pero esta nunca realizada pues es imposible; es necesariamente una representación fantasmática, y como tal sólo puede ser imaginaria. Por ello se representa en Los Conflictos como una esperanza, es decir, como un escenario idealizado por-venir, aún no realizado y, en estricto rigor, 
irrealizable. Es por ello (¿sólo?) simbolizado por los gestos de las manos. Pero, no por ser imaginaria es inefectiva. Es justamente este carácter imaginario de la representación de la sociedad reconciliada lo que alimenta la esperanza y el deseo. Las manos evocan un escenario idealizado de la nación reconciliada, y un mito de una comunidad nacional (aunque sea una comunidad imaginada, (Anderson 1993). La efectividad de este mito, de esta fantasía de la sociedad reconciliada, es de tipo ideológica: es capaz de motivar proyectos políticos efectivos (Boeninger 1997, Fernàndez 1997, Ortega 1992), de difundir una estrategia política ocultando o justificando sus limitaciones como si fuera un modelo ejemplar a imitar (Moulian 1994, 1997), y de conducir a agentes a la autorepresión de demandas fundamentales sobre la base de una auto-justificación (Cuevas 2001).

Consistente con la evidencia recolectada para investigaciones anteriores sobre los discursos dominantes sobre la democracia durante la transición y la instalación de la democracia, he encontrado aquí que los discursos contemporáneos sobre democratización, nación e identidad resultan estar altamente entrelazados (Cuevas 2001, 2008, 2009, 2014, 2015a). A pesar de expresarse en diferentes códigos y registros simbólico intelectual en textos de ciencia política, sociología política, y ensayo político, y visual imaginario en MVN y otras expresiones plásticas, dominan los mismos significantes del campo semiótico del consenso y la reconciliación. En ambos códigos se recurre a similares formas metafóricas o paradigmáticas de representación: relatos sobre transición vía transacción, transición negociada, democracia consensual, reconciliación nacional, unidad y consenso. Relatos sobre heridas en el alma de la nación, sobre la necesidad de superar el conflicto y promover el perdón, sobre procesos de aprendizaje, etc. Todos estos significantes ocuparon un lugar clave en el discurso de la elite política a fines de la década de 1980, durante los 1990 y la primera mitad de los 2000.

\section{Referencias bibliográficas}

Althusser, Louis (1969), For Marx, Verso, Londres. Allen Lane, The Penguin Press. 
(1990), Philosophy and the Spontaneous Philosophy of the

Scientists \& Other Essays, Verso, Londres.

(2003), "Ideología y aparatos ideológicos de estado", en Ideología: un mapa de la cuestión, Siglo XXI, Buenos Aires.

(1993), Comunidades imaginadas. Reflexiones sobre el origen y la difusión del nacionalismo, Fondo de Cultura Económica, México

Archer, Margaret (1997), Cultura y Teoría Social, Nueva Visión, Buenos Aires.

Ariztía, Tomás (Editor) (2012), Produciendo lo Social: usos de las ciencias sociales en el Chile reciente, Santiago, Ediciones UDP.

Aylwin, Patricio (1992), La Transición Chilena: Discursos Escogidos 1990-1992, Andrés Bello and Secretaría de Comunicación y Cultura, Ministerio Secretaría General de Gobierno, Santiago de Chile.

Bourdieu, Pierre y Wacquant, Loïc (1992) An Invitation to Reflexive Sociology. Chicago: Polity Press.

Carpentier, Nico y De Cleen, Benjamin (2007), Bringing Discourse Theory into Media Studies. The applicability of Discourse Theoretical Analysis (DTA) for the Study of media practises and discourses, Journal of Language and Politics 6 (2): 265-293.

Carpentier, Nico y Spinoy, Erik (eds.) (2008), Discourse Theory and Cultural Analysis: Media, Arts and Literature, Malden, Hampton Press.

Boeninger, Edgardo (1997), Democracia en Chile: Lecciones para la Gobernabilidad, Editorial Andrés Bello, Santiago de Chile.

Brunner, José (1988), Un Espejo Trizado. Ensayos sobre Cultura y Politicas Culturales, Santago, FLACSO. 
Cuevas, Hernán (2001), "La nueva democracia chilena”, en Estabilidad, crisis y organización de la política. Lecciones de medio siglo de historia chilena, FLACSO, Santiago de Chile.

(2008), "Chilean traumatized identity", en Discourse theory and cultural analysis : media, arts and literature, Hampton Press, Cresskill.

(2009), La Cuestión de la Identidad Chilena, en C. Fuentes (ed.) Chile 2008: Percepciones y Actitudes Sociales, ICSO-UDP, Santiago.

(2014), Discurso militar e identidad nacional chilena, Polis, Revista Latinoamericana, 13 (38): 467-498.

(2015a), "The (im)possible representation of national history: national identity, memory and trauma in Memoria Visual de una Nación by Mario Toral", en Družboslovne Razprave, XXXI, 79.

(2015b), 1986. El martirio de Carmen Gloria Quintana y Rodrigo Rojas, El Mostrador, 22 de Agosto de 2015 http://www.elmostrador.cl/noticias/opinion/2015/08/22/1986-el-martirio-de-carmengloria-quintana-y-rodrigo-rojas/ (29.06.2016).

(2015c), Ernesto Laclau y su concepto de discurso post-marxista, Pléyade 16: 33-47.

Culler, Jonathan (1998), Sobre la deconstrucción: teoría y crítica después del estructuralismo, Cátedra, Madrid.

Debord, Guy (1977), The Society of the Spectacle, Zone Books, Nueva York.

De Ramón, Armando (2003), Historia de Chile. Desde la invasión incaica hasta nuestros dias (1500-2000), Santiago, Catalonia.

Derrida, Jacques (2005), De la gramatología, Siglo XXI, México DF.

Du Gay, Paul et al., 2013), Doing Cultural Studies, Londres, Sage. 
Eco, Umberto (1992), Obra Abierta, Planeta Agostini, Barcelona.

Edwards, Alberto (1936), La Fronda Aristocrática en Chile, Ediciones Ercilla, Santiago de Chile.

Evans, Jessica y Hall, Stuart (1999), “What is Visual Culture?”, en Visual Culture: The Reader, Sage, Londres.

Evans, Dylan (1996), An Introductory Dictionary of Lacanian Psychoanalysis, Routledge, Londres.

Fernández, Mario (1998), "El Sistema Político Chileno: Características y Tendencias", en Chile en los Noventa, Presidencia de la República-Dolmen Ediciones, Santiago de Chile.

Fink, Bruce (1995), The Lacanian Subject: Between Language and Jouissance, Princeton University Press, Princeton.

Fiske, John (1990), Introduction to Communication Studies, Routledge, Londres.

Foxley, Alejandro (2003), "El Alma de Chile", La Segunda, 12 de septiembre.

Fundación Futuro (2003), “¿Qué Pensamos los Chilenos a 30 años del Golpe Militar?" http://www.fundacionfuturo.cl/estudios pub.php?id=35\&valor=1.

Garretón, Manuel A. (2008) Del post-pinochetismo a la sociedad democrática. Globalización y Política en el bicentenario, Debate, Santiago de Chile.

Geras, Norman (1987), Post-Marxism?, NLR 163: 40-82.

Glynos, Jason (2001) "The Grip of Ideology: A Lacanian Approach to the Theory of Ideology”, en Journal of Political Ideologies 6 (2).

Griggs y Howarth, David (2011), Discourse and practice: using the power of well being, Evidence \& Policy 7 (2): 213-226 
Hall, Stuart (1980), Cultural studies: two paradigms, Media, Culture \& Society 2: 57-72.

(1991) "Reconstruction Work: Images of Post-war Black Settlement" en Family Snaps: The Remaining of Domestic Photography, Virago, Londres.

(1993) "Encoding, Decoding", en The Cultural Studies Reader, Routledge, Londres.

(2010), "El trabajo de representación”, en Stuart Hall, Sin Garantías. Trayectorias y problemáticas en estudios culturales, Envión Editores, Popayán.

Hall, Stuart (et al.) (1982 [1978]) Policing the Crisis. Mugging, the State, and Law and Order. The Macmillan Press, Londres.

Howarth, David et al. (Eds) (2000), Discourse Theory and Political Analysis: Identities, Hegemonies, and Social Change, Manchester University Press, Manchester.

Howarth, David y Torfing, Jacob (2005), Discourse Theory in European Politics. Identity, Policy and Governance, Palgrave, Londres.

Howarth, David y Stavrakakis, Yannis (2000), "Introducing Discourse Theory and Political Analysis", en Discourse Theory and Political Analysis: Identities, Hegemonies, and Social Change, Manchester University Press, Manchester.

Huneeus, Carlos (2003), Chile, Un País Dividido. La Actualidad del Pasado, Catalonia, Santiago de Chile.

Ivelic, Milan y Galaz, Gaspar (1988), Chile, arte actual, Ediciones Universitarias de Valparaíso, Valparaíso.

Lacan, Jacques (1991), The Seminar of Jacques Lacan, Book I, Freud's Papers on Technique 1953-1954, J.-A. Miller (ed.), Nueva York, W.W. Norton \& Company.

Laclau, Ernesto (1986), Política e Ideología en la Teoría Marxista. Capitalismo, Fascismo, Populismo, Siglo XXI, Madrid. 
(1993), "Discourse", en The Blackwell Companion to Political

Philosophy, Blackwell, Londres.

(1994), "Introduction", en E. Laclau (ed.) The Making of Political Identities, Verso, Londres.

(1996), Emancipación y diferencia, Ariel, Buenos Aires.

(1997), Hegemonía y Antagonismo. El Imposible Fin de Lo Político, Cuarto Propio, Santiago.

(2000), Nuevas reflexiones sobre la revolución de nuestro tiempo, Nueva Visión, Buenos Aires.

(2003), "Identidad y hegemonía: el rol de la universalidad en la construcción de lógicas políticas", en Contingencia, hegemonía, universalidad: diálogos contemporáneos en la izquierda, Fondo de Cultura Económica, Buenos Aires.

(2005) La Razón Populista, FCE, Buenos Aires.

(2008), “Atisbando el futuro", en Laclau: aproximaciones críticas a su obra, Fondo de Cultura Económica, Buenos Aires.

(2014), The Rhetorical Foundations of Society, Verso, Londres.

Laclau, Ernesto y Mouffe, Chantal (2000), "Postmarxismo sin Pedido de Disculpas", en E. Laclau, Nuevas reflexiones sobre la revolución de nuestro tiempo, Nueva Visión, Buenos Aires, pp. 111-145.

(2001), "Preface to the Second Edition", en E. Laclau y C. Mouffe, Hegemony and Socialist Strategy. Towards a Radical Democratic Politics, $2^{a}$ ed, Verso, Londres.

(2010), Hegemonía y estrategia socialista: hacia una radicalización de la democracia, Fondo de Cultura Económica, Buenos Aires. 
Laclau, Ernesto y Zac, Lilian (1994) "Minding the Gap: The Subject of Politics", en The Making of Political Identities, Verso, Londres.

Laitin, David (1988), "Political Culture and Political Preferences", en American Political Science Review 82 (2): 589-597.

Larraín, Jorge (2006), Changes in Chilean identity: thirtyyears after the military coup, Nations and Nationalism 12 (2): 321-338.

Lechner, Norbert (1990), "Hay Gente que Muere de Miedo", en Los Patios Interiores de la Democracia, Fondo de Cultura Económica, Santiago de Chile.

Mouffe, Chantal (2001), "Every Form of Art has a Political Dimension. Chantal Mouffe interviewed by Rosalyn Deutsche, Branden W. Joseph and Thomas Keenan”, en Grey Room 2 (Winter 02), pp. 98-125.

(2013), Agonistics, Londres, Verso.

Moulian, Tomás (1994), Limitaciones de la transición a la democracia en Chile, Proposiciones 25: 25-33.

(1997) Chile Actual: Anatomía de un Mito, Lom, Santiago.

Nichols, Bill (1985), "The Analysis of Representational Images", en John and Jeremy Hawthorn (Eds.) Communication Studies: An Introductory Reader, Edward Arnold, Londres.

Ortega, Eugenio (1992), Historia de una alianza política: el partido Socialista de Chile y el partido Demócrata Cristiano: 1973-1988, CED-CESOC, Santiago.

Panizza, Francisco (ed.) (2009), El Populismo como Espejo de la Democracia, FCE, Buenos Aires.

Sayyid, Bobby y Zac, Lilian (1998), "Political Analysis in a World without Foundations", en Research Strategies in Social Sciences: A Guide to New Approaches, Oxford University Press, Oxford. 
Silva, Patricio (1999), "Collective Memories, Fears and Consensus: The Political Psychology of the Chilean Democratic Transition”, en Societies of Fear: The Legacy of Civil War, Violence and Terror in Latin America, Zed Books, Londres.

Silva Henríquez, Raúl (1986), El Alma de Chile, Santiago, Cieplan, Santiago de Chile.

Slack, J. D. (1996) "The Theory and Method of Articulation in Cultural Studies", en Stuart Hall: Critical Dialogues in Cultural Studies, Routledge, Londres.

Stavrakakis, Yannis (2007) Lacan y lo político, Prometeo Libros, Buenos Aires.

Strasma, Mary (2003) "History in its Walls: La Moneda, Memory, and Reconciliation in Post-authoritarian Chile" artículo presentado en FLACSO Chile, 5th of August 2003.

Toral, Mario (1999a) Memoria Visual de una Nación, Santiago, Metroarte.

(1999b) "El Grandioso Mural Incómodo de Mario Toral, entrevista con José Miguel Varas", en Rocinante N 7.

(2016), Mario Toral, pintor chileno: "Quiero ser como Goya y Picasso, que se involucran con la belleza y la verdad", La Tercera, 16 de enero. url http://fw.to/eNvioTP (17.02.2016)

Turner, Graeme (2003), British Cultural Studies. An Introduction, Routledge, Londres.

Vezovnik, Andreja (2012), The Construction of Political Subjectivity: The Case of Inmigrant Workers in Slovenia, Pléyade 10: 37-66.

Vial, Gonzalo (1981-1987), Historia de Chile (1891-1973), 4 Vols, Santillana del Pacífico, Santiago de Chile.

Villalobos, Sergio (1980), Historia del Pueblo Chileno, ICHEH, Santiago de Chile. 
Vitale, Luis (1993-1998), Interpretación Marxista de la Historia de Chile, 6 vols, Lom, Santiago de Chile.

(1999), Para Recuperar la Memoria Histórica: Frei, Allende y Pinochet, Lom, Santiago de Chile.

Žižek, Slavoj (1992), El sublime objeto de la ideología, Siglo XXI, México.

(2000), "Más allá del análisis del discurso", en Nuevas reflexiones sobre la revolución de nuestro tiempo, Nueva Visión, Buenos Aires.

(2003), "Introducción”, en Ideología: un mapa de la cuestión, Siglo XXI, Buenos Aires. 
Revista de la Academia/ISSN 0719-6318

Volumen 22/Primavera 2016

Hernán Cuevas Valenzuela

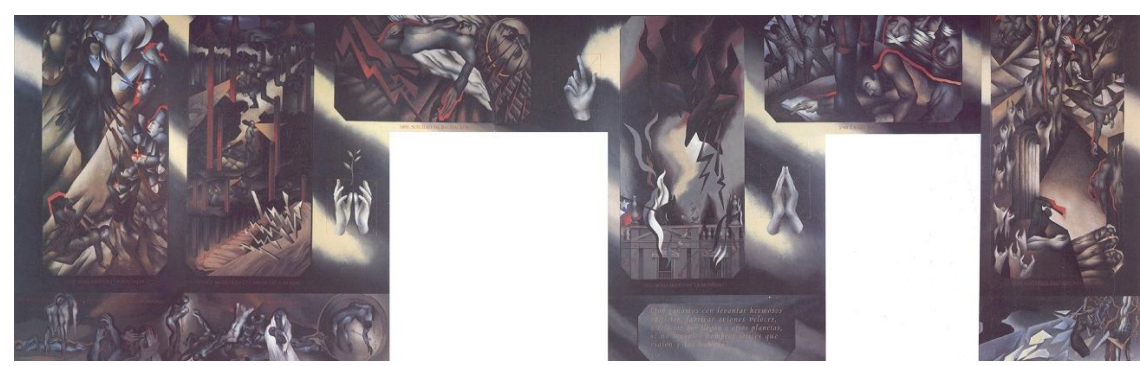

Figura 1

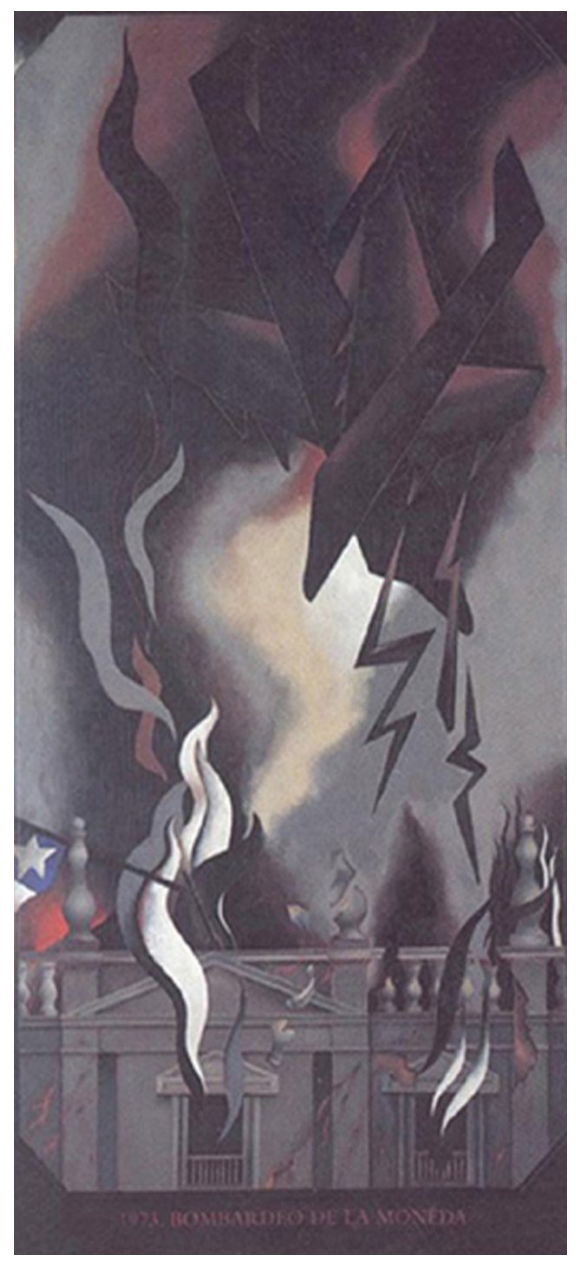

Figura 2 


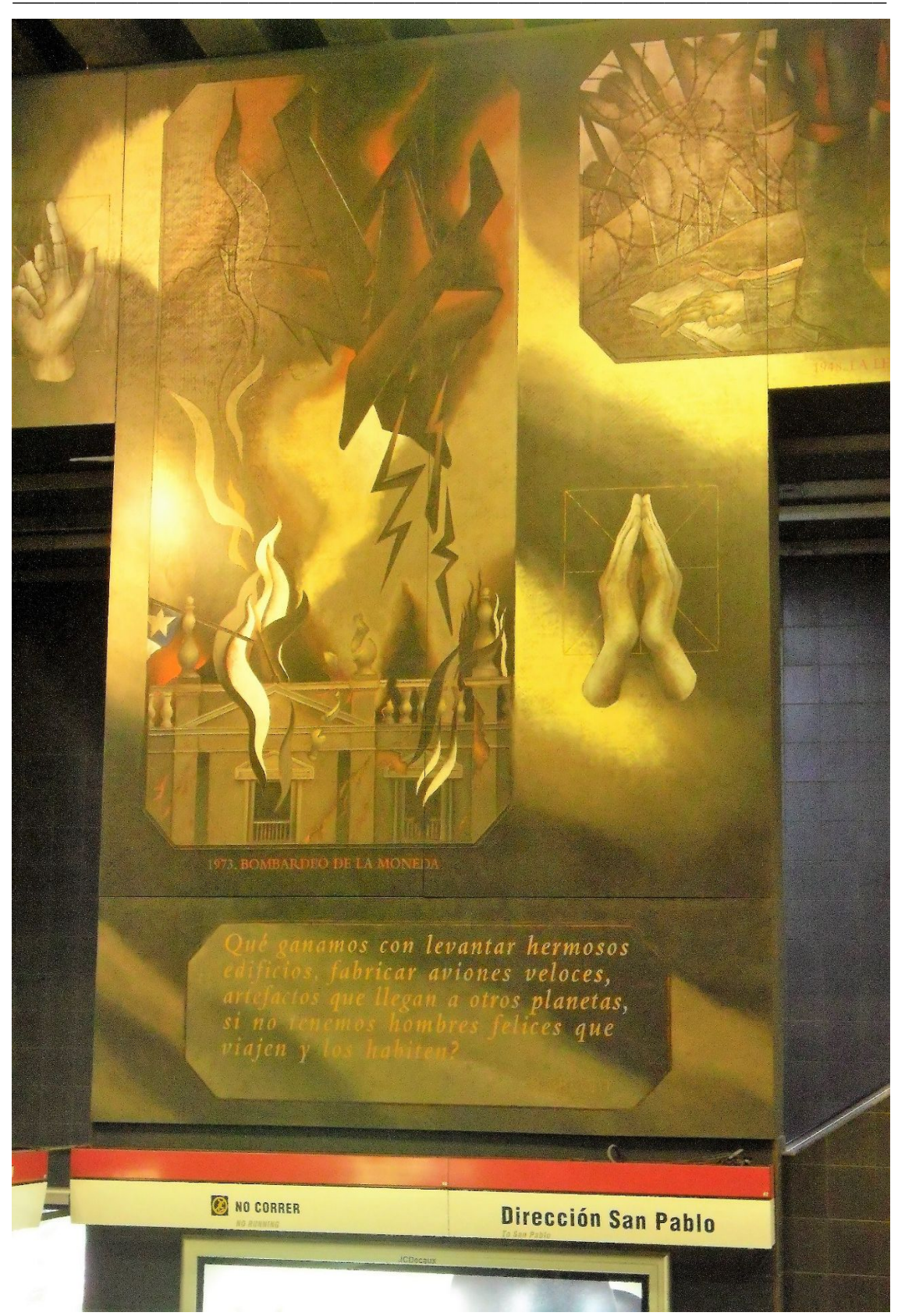

Figura 3 
Revista de la Academia/ISSN 0719-6318

Volumen 22/Primavera 2016

Hernán Cuevas Valenzuela

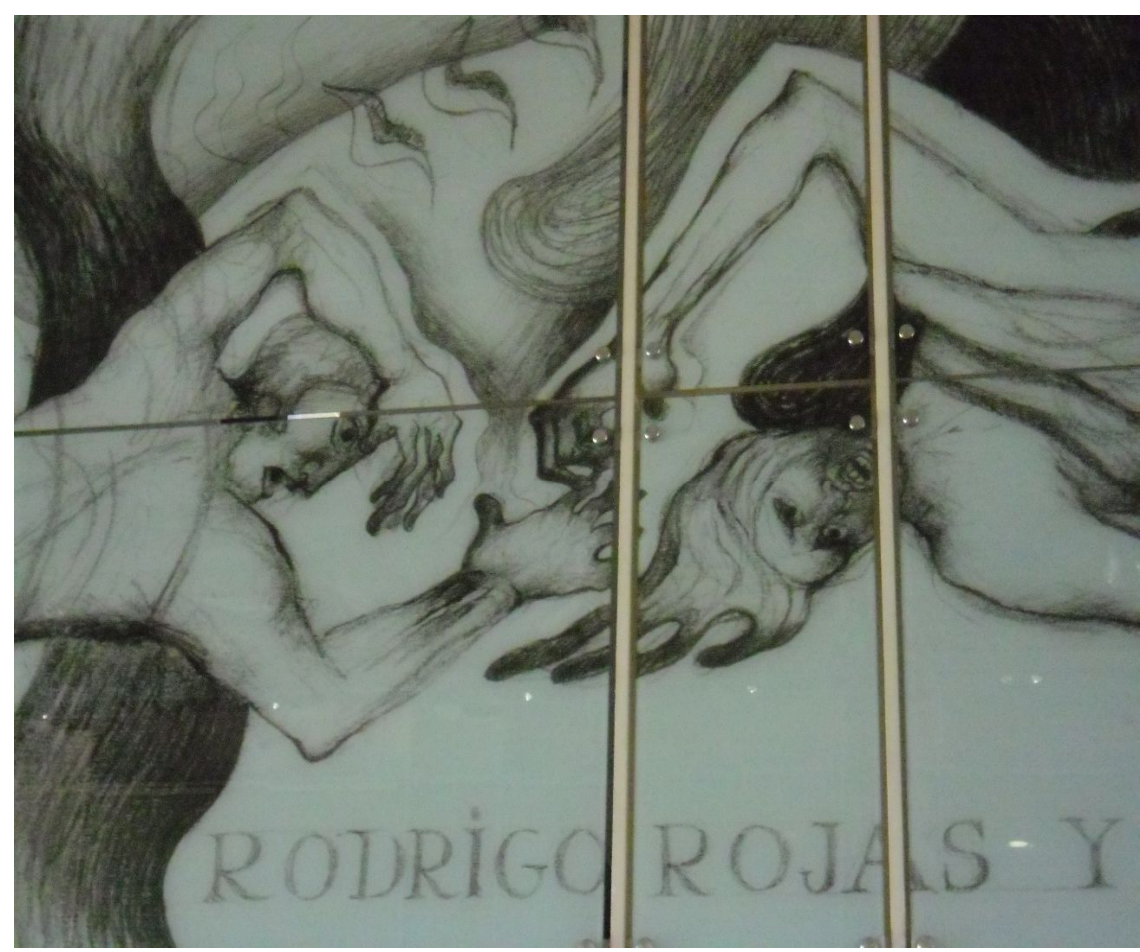

Figura 4 


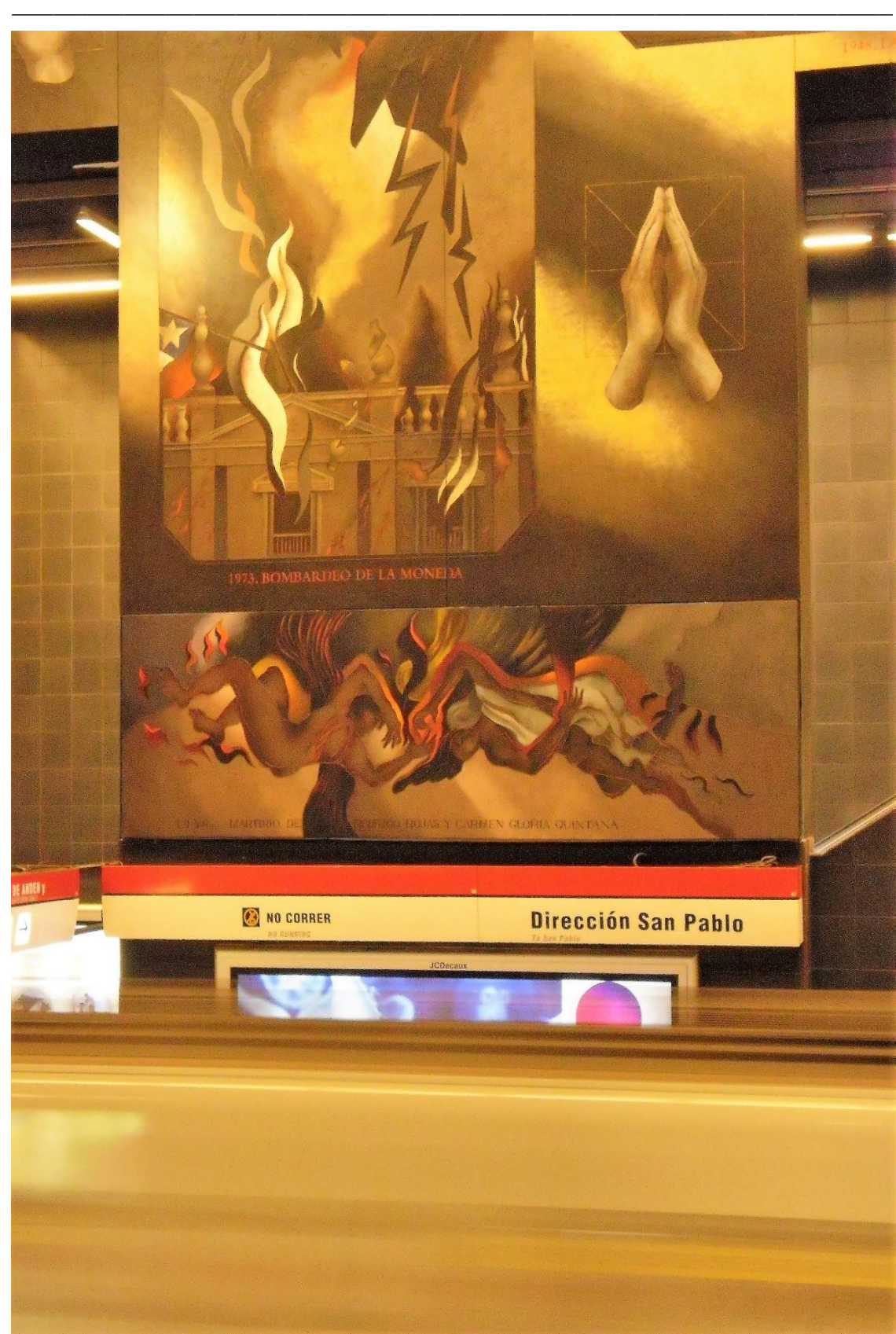

Figura 5 